\title{
Modeling the relationship of aeration, oxygen transfer and treatment performance in aerated horizontal flow wetlands
}

\author{
Johannes Boog ${ }^{a b *}$, Thomas Kalbacher ${ }^{c}$, Jaime Nivala ${ }^{a}$, Nicolas Forquet ${ }^{d}$, Manfred van
} Afferden ${ }^{a}$, Roland A. Müller ${ }^{a}$

2018-12-19

${ }^{a}$ Helmholtz Centre for Environmental Research (UFZ), Centre for Environmental Biotechnology (UBZ), Permoserstrasse 15, 04318 Leipzig, Germany

${ }^{\mathrm{b}}$ Dresden University of Technology, Applied Environmental System Analysis, Helmholtzstraße 10, 01069 Dresden

${ }^{c}$ Helmholtz Centre for Environmental Research (UFZ), Department of Environmental Informatics, Permoserstrasse 15, 04318 Leipzig, Germany

${ }^{\text {d} I R S T E A, ~ U R ~ R E V E R S A A L, ~ L y o n-V i l l e u r b a n n e ~ c e n t r e, ~} 5$ rue de la Doua, CS70077, 69626, Villeurbanne cedex, France

*Corresponding author: Johannes Boog, johannesboog@yahoo.de

\section{Highlights:}

- Development of a process model for aerated HF wetlands treating sewage

- Model calibration and validation by pilot-scale experiments

- Aeration controls location and gradients of treatment performance

- $\mathrm{O}_{2}$-transfer coefficient depended logarithmically on air flow rate

- Optimal air flow rate to treat similar influent strengths $\approx 150-200 \mathrm{~L} \mathrm{~h}^{-1} \mathrm{~m}^{-2}$

Keywords: constructed wetland, treatment wetland, reactive transport modeling, process simulation, nature-based technology, optimization,

\section{Graphical Abstract}
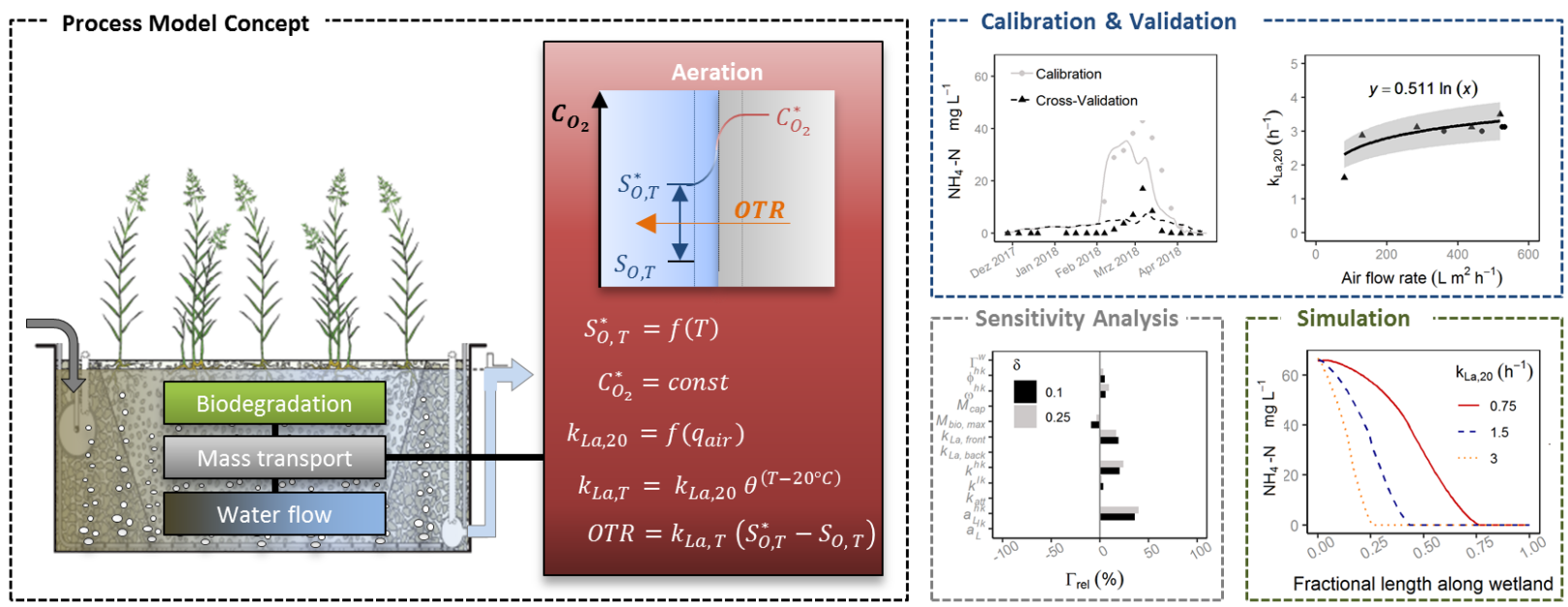


\begin{abstract}
Mechanical aeration is commonly used to improve the overall treatment efficacy of constructed wetlands. However, the quantitative relationships of air flow rate (AFR), water temperature, field oxygen transfer and treatment performance have not been analyzed in detail until today.

In this study, a reactive transport model based on dual-permeability flow and biokinetic formulations of the Constructed Wetland Model No. 1 (CWM1) was developed and extented to 1) simulate oxygen transfer and treatment performance of organic carbon and nitrogen of horizontal flow (HF) aerated wetlands treating domestic sewage, and, 2) to investigate the dependence of oxygen transfer and treatment performance on AFR and water temperature.

Conservative tracer transport as well as reactive transport of dissolved oxygen (DO), soluble and total chemical oxygen demand $\left(\mathrm{COD}_{\mathrm{s}}, \mathrm{COD}_{\mathrm{t}}\right), \mathrm{NH}_{4}-\mathrm{N}$ and $\mathrm{NO}_{\mathrm{x}}-\mathrm{N}$ measured in pilot-scale experiments were simulated with acceptable accuracy $\left(\bar{E}_{1}=0.39 \pm 0.26\right)$. A prediction equation for the volumetric oxygen transfer coefficient was found to be: $k_{L a, 20}=0.511 \ln (\mathrm{AFR})$. Treatment performance depended on $k_{L a, 20}$ in a non-linear manner. A local sensitivity analysis of the calibrated parameters revealed porosity, hydraulic permeability and dispersion length of the fast flow field as well as $k_{L a, 20}$ as most important.

Simulated changes in water temperature from $2.5-20.0{ }^{\circ} \mathrm{C}$ did not substantially affect oxygen transfer. An optimal AFR for a spatially and temporally continuous aeration pattern for wetlands treating similar influent was estimated to $150-200 \mathrm{~L} \mathrm{~h}^{-1} \mathrm{~m}^{-2}$.

These results can support wetland design in setting the AFR to meet the oxygen demand of a specific influent strength. Furthermore, this study provides insights into aeration mechanisms of aerated wetlands and highlights the benefits of process modeling for in-depth system analysis.
\end{abstract}




\section{Introduction}

Aerated wetlands, a type of nature-based technologies, have been successfully applied for domestic and industrial wastewater treatment (Ilyas and Masih, 2017). However, detailed knowledge of the link of aeration with treatment performance, especially the quantitative relationship of air flow rate (AFR) and temperature with field oxygen transfer and their effects on treatment performance, is still lacking. Such knowledge is of importance to support design optimization (e.g. setting the AFR to meet influent specific oxygen demands) as well as to further study the degradation of pollutants (e.g. nitrogen and emerging organic contaminants) that require specific redox conditions for removal, which can be controlled by varying the AFR. Given such knowledge, redox conditions could be systematically controlled over space and time, unfolding the complete removal potential of aerated wetlands and increasing their economic efficiency.

The effect of AFR and aeration time on carbon and nitrogen removal has been investigated in a few lab-scale studies using artificial wastewater (Wu et al., 2016; Zhou et al., 2018), however, up-scaling to full-scale is difficult. In contrast, available pilot-scale studies (Li et al., 2014; Uggetti et al., 2016) provide less fundamental information on the relationship of AFR and treatment performance as such studies are expensive, time consuming and therefore, limited in their experimental capabilities.

More detailed information on aeration and the link to treatment performance in aerated wetlands can be gained through comparing experimental with process modeling results. Process modeling has been successfully applied to simulate treatment performance and to support engineering design of conventional horizontal flow (HF) and vertical flow (VF) treatment wetlands (Langergraber, 2017; Pálfy et al., 2015; Samsó and García, 2013; Sanchez-Ramos et al., 2017), in contrast, not yet for aerated wetlands. Several treatment wetland models exist, however, the most advanced ones, HYDRUS Wetland Module (Langergraber and Simunek, 2012) and Bio_PORE (Samsó and García, 2013) are implemented in closed-source codes of commercial software. This restricts access to their use and limits further model developments that are necessary to simulate oxygen transfer by mechanical aeration in aerated wetlands. Open-source reactive transport codes such as OpenGeoSys (Kolditz et al., 2012), Tough (Pruess, 2004) or MIN3P (Mayer et al., 2002) are potential alternatives. Boog (2017) already implemented a model of a conventional HF wetland into the OpenGeoSys framework, however, the extensions to simulate aerated wetlands were not included.

In this study, a reactive transport model (RTM) for aerated HF wetlands was developed and implemented into the OpenGeoSys framework. Specific study objectives were: 1) to simulate oxygen transfer and treatment performance of organic carbon and nitrogen of aerated HF wetlands treating domestic sewage, and, 2) to investigate the dependence of the oxygen transfer coefficient on AFR and water temperature as well as the link to treatment performance gradients and efficacy. Outdoor pilot-scale experiments with real wastewater were conducted for model calibration and validation. Local sensitivity analysis were carried out to identify most important model parameters. Then prediction scenarios were simulated to evaluate the effects of AFR and water temperature on treatment performance. Thus, this study deepens the knowledge on aeration in aerated wetlands and, at the same time, provides relevant information for process simulation and engineering practice.

\section{Material and Methods}

\subsection{Experimental Site and System Description}

Pilot-scale experiments were carried out at the treatment wetland research facility in Langenreichenbach, Germany (Nivala et al., 2013) using two identical aerated HF treatment wetlands named Test and Control (Figure 1). Both wetlands were similarly designed as the wetland HAp described in Nivala et al. (2013). Briefly, the two wetlands measured $4.7 \mathrm{~m}$ in length and $1.2 \mathrm{~m}$ in width with a saturated depth of $0.9 \mathrm{~m}$. Both systems were planted with $P$. australis. Medium gravel $(8-16 \mathrm{~mm})$ was used as main media and coarse gravel (16-32 mm) for in- and effluent zones. Aeration was provided by a network of drip irrigation pipes on the wetland bottom connected to electric diaphragm blowers that operated $24 \mathrm{~h} \mathrm{~d}^{-1}$. The Control was 
a)
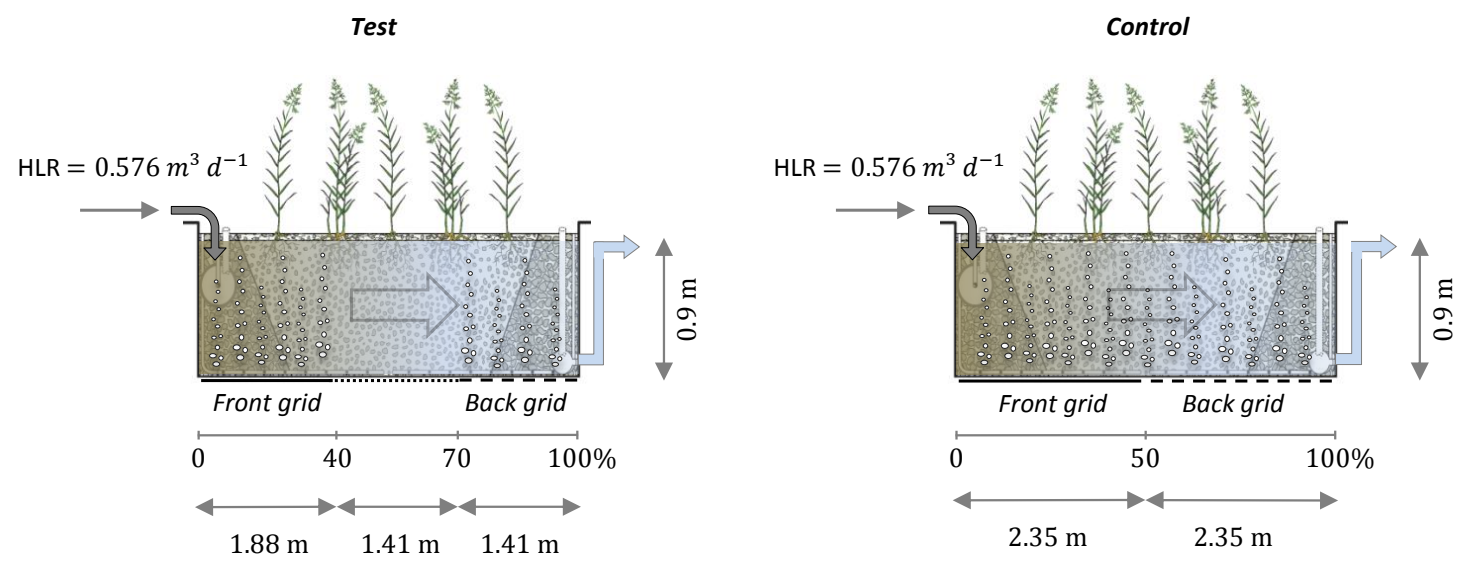

b)
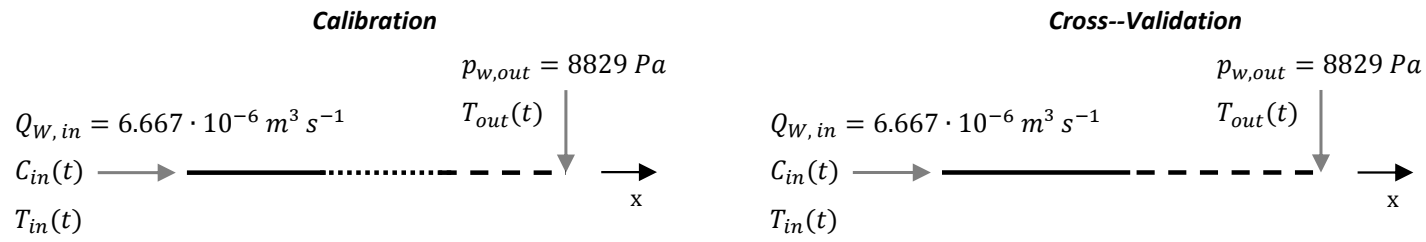

Figure 1: Experimental systems (a) and corresponding model domains for the calibration on Test and cross-validation on Control (b).

continuously aerated over the entire area of the wetland. Instead, aeration in the Test was restricted to 0-40\% and $70-100 \%$ of the length (no aeration from 40-70\%). Both wetlands were loaded with $12 \mathrm{~L}$ of primarily treated domestic sewage every $30 \mathrm{~min}$ at a dosing rate of $5 \mathrm{~L} \mathrm{~min}{ }^{-1}$, which corresponds to a hydraulic loading rate (HLR) of $0.576 \mathrm{~m}^{3} \mathrm{~d}^{-1}$. Pretreatment was achieved in a three-chamber septic tank with a nominal hydraulic retention time (nHRT) of 3.5 days. In- and outflow were recorded via a magnet inductive flow meter (Endress + Hauser, Promag 10) and a tipping counter, respectively. Both wetlands were constructed and planted in August 2014; commissioning took place in September 2014.

\section{$2.2 \quad$ Hydraulic Tracer Experiments}

Tracer experiments using a single tracer injection were conducted from September 26th to October 11 th 2014 to investigate wetland hydraulics and to calibrate the conservative transport model. Briefly, a defined amount of the tracers bromide $\left(60 \mathrm{~g}\right.$ of dried $\mathrm{KBr}, 2 \mathrm{~h}$ at $\left.105^{\circ} \mathrm{C}\right)$ and uranine $\left(2.5 \mathrm{~mL}\right.$ of a $200 \mathrm{~g} \mathrm{~L}^{-1}$ solution) were diluted in $12 \mathrm{~L}$ of influent and injected as a replacement of one dosing event at the same dosing rate into the inlet distribution pipe of each wetland. An auto-sampler took grab samples of the effluent. Bromide was analyzed using inductively coupled plasma atomic emission spectroscopy (ICP-AES, Thermo Fisher Scientific Gallery Plus), and, for concentrations less than $1 \mathrm{mg} \mathrm{L}^{-1}$, with anionic ion chromatography (DIN 38405 D19, DIONEX DX500). Effluent uranine concentration was detected on-line by a fluorometer (Cyclops-7, Nordantec). Mean tracer retention time $\tau$, nominal hydraulic tracer retention time (nHRT), hydraulic efficiency $e_{v}$, number of tanks-in-series (NTIS) and tracer mass recovery $m_{\text {tracer,rec }}$ were calculated according to Kadlec and Wallace (2009) (Section S1.1). 


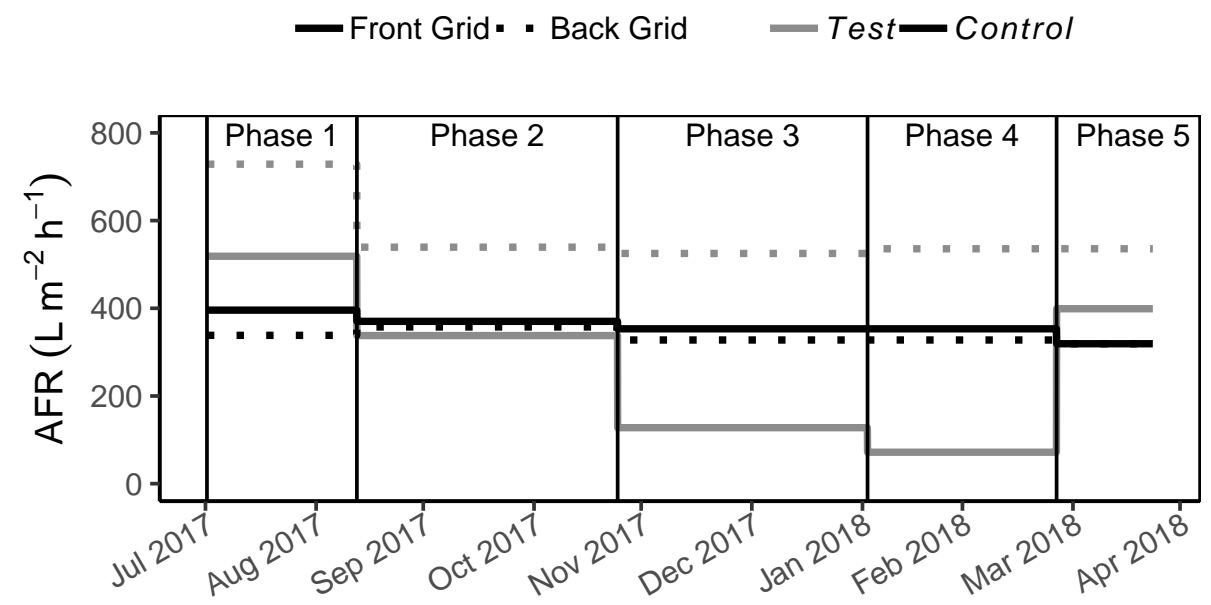

Figure 2: AFR adjustment during the aeration adaptation experiment in Test and Control. Front and Back Grid refer to aeration grid positions defined in Figure 1.

\subsection{Aeration Adaptation Experiment}

Both wetlands were operated at a constant AFR from September 2014 to September 2017. It was expected that porewater and effluent concentrations of $\mathrm{DO}, \mathrm{NH}_{4}-\mathrm{N}$ and $\mathrm{NO}_{3}-\mathrm{N}$ strongly depend on oxygen transfer. From September 2017 AFR in the Test was reduced stepwise (Phases 1-4) with the intention to lower oxygen transfer and investigate how porewater and effluent concentrations of $\mathrm{DO}, \mathrm{NH}_{4}-\mathrm{N}$ and $\mathrm{NO}_{3}-\mathrm{N}_{\text {change }}$ accordingly. In Phase 5 AFR was reset to values of Phase 2 (Figure 2). Air flow in the Control was left unchanged throughout the experiment. AFR was measured using a thermal mass flow meter (TSI 4043, TSI $\mathrm{GmbH}$ ). Grab samples of in- and effluent were taken on a weekly basis to assess treatment efficacy. Grab samples of porewater were taken one to two times a month at 10,20,40,55, 70 and $85 \%$ of the wetland length and a depth of $0.5 \mathrm{~m}$ to measure pollutant concentration gradients.

\subsection{Water Quality Analysis}

All grab samples of the aeration adaptation experiment were analyzed according to Nivala et al. (2013). Briefly, redox potential (Eh, SenTix ORP, WTW Weilheim), electric conductivity (EC), dissolved oxygen (DO, ConOx, WTW Weilheim), temperature $(T)$ and $\mathrm{pH}$ (SenTix $\mathrm{pH}$ ) were measured using a hand-held meter (Multi 359i, WTW Weilheim) and a pH meter at the site. Samples were stored in a cooling box until further analysis within $24 \mathrm{~h}$ for: five-day carbonaceous biochemical oxygen demand $\left(\mathrm{CBOD}_{5}\right.$, DIN 38409H52, WTW OxiTOP), total organic carbon (TOC, DIN EN 1484, Shimadzu TOC-VCSN,), dissolved organic carbon (DOC, DIN EN 1484, Shimadzu TOC-VCSN, filtration by $0.45 \mu \mathrm{m}$ ceramic filter), total nitrogen (TN, DIN EN 12660, Shimadzu TNM-1), dissolved nitrogen (DN, DIN EN 12660, Shimadzue TNM-1, filtration by $0.45 \mathrm{~m}$ ceramic filter), ammonia nitrogen $\left(\mathrm{NH}_{4}-\mathrm{N}\right.$, DIN 38406E5, Thermo Fisher Scientific Gallery Plus), nitrate nitrogen $\left(\mathrm{NO}_{3}-\mathrm{N}\right.$, DIN 38405D9, Thermo Fisher Scientific Gallery Plus) and nitrite nitrogen $\left(\mathrm{NO}_{2}-\mathrm{N}\right.$, DIN 38405D10, Thermo Fisher Scientific Gallery Plus). Occasional analysis of total chemical oxygen demand $\left(\mathrm{COD}_{\mathrm{t}}\right.$, LCK514 \& LCK314, Hach-Lange), soluble chemical oxygen demand $\left(\mathrm{COD}_{\mathrm{s}}\right.$, LCK514 \& LCK314, Hach-Lange, filtration by $0.45 \mu \mathrm{m})$ and chloride (Cl, LCK311, Hach-Lange) were conducted using test-kits and a spectrophotometer (DR3900 Hach-Lange). Missing values were left blank. Outliers were excluded from further analysis if related to site malfunctions or maintenance. 


\subsection{Conceptual and Mathematical Model}

With respect to the box-shaped geometry of the experimental systems concentrations gradients in width and depth were neglected for three reasons: 1) larger gradients in length, 2) absence of measurements in width and depth and 3) model simplicity. Therefore, the model is limited to the length direction. Water flow was modeled using a dual-permeability approach that assumes to coupled and overlapping flow domains (a slow flow and a fast flow domain; also termed matrix and fracture domain or low and high conductivity domain) to describe non-equilibrium flow (Gerke and van Genuchten, 1993). The dual-permeability model implemented in OpenGeoSys uses the pressure-based form of two coupled Richards equations (Kolditz et al., 2012):

$$
\begin{aligned}
\phi^{h k} \rho_{w} \frac{\partial S^{h k}}{\partial p_{c}^{h k}} \frac{\partial p_{c}^{h k}}{\partial t}+\rho_{w} \nabla\left(\frac{k_{r e l}^{h k} k^{h k}}{\mu_{w}}\left(\nabla p_{w}^{h k}-\rho_{w} \mathbf{g}\right)\right) & =Q_{w}+\rho_{w} \frac{\Gamma_{w}}{\omega^{h k}} \\
\phi^{l k} \rho_{w} \frac{\partial S^{l k}}{\partial p_{c}^{l k}} \frac{\partial p_{c}^{l k}}{\partial t}+\rho_{w} \nabla\left(\frac{k_{r e l}^{l k} k^{l k}}{\mu_{w}}\left(\nabla p_{w}^{l k}-\rho_{w} \mathbf{g}\right)\right) & =Q_{w}+\rho_{w} \frac{\Gamma_{w}}{1-\omega^{l k}} \\
\Gamma_{w} & =\alpha^{*} \frac{\mathrm{k}_{\alpha}}{\mu_{w}}\left(p_{w}^{l k}-p_{w}^{h k}\right)
\end{aligned}
$$

were the superscripts ${ }^{h k}$ and ${ }^{l k}$ denote the fast and slow flow field (Table 1). Transport of solutes and particulates is modeled via advection and dispersion; heat transport via convection and conduction (Kolditz et al., 2012). Biodegradation is described using the formulation of CWM1 (Langergraber et al., 2009). Additionally, the following extensions proposed by Samsó and García (2013) were included: $1^{\text {st }}$-order attachment-detachment processes for slowly biodegradable $\mathrm{COD}_{\mathrm{t}}\left(X_{S}\right)$ and particulate inert $\mathrm{COD}_{\mathrm{t}}\left(X_{I}\right)$, which separates both components into a mobile $(\mathrm{m})$ and immobile $\left.{ }^{\mathrm{im}}\right)$ one $\left(X_{S}=X_{S, m}+X_{S, i m}, X_{I}=\right.$ $\left.\left.X_{I, m}+X_{I, i m}\right) ; 2\right)$ a maximum biomass concentration $\left(M_{b i o, \max }\right)$ according to substrate diffusion limitation; 3 ) the maximum concentration of inert particulate $\mathrm{COD}_{\mathrm{t}}\left(M_{c a p}\right)$ that limits attachment of $X_{I, m}$ (the limitation of $M_{c a p}$ on bacterial growth as proposed by Samsó and García (2013) is not considered in this study). $M_{b i o, \max }$ is multiplied with the growth functions of the $k$-th bacterial group $r_{k, \text { growth }}$ as:

$$
r_{k, \text { growth }, \text { new }}=r_{k, \text { growth }}\left(1-\frac{\sum X_{k}}{M_{\text {bio, } \max }}\right)
$$

Aeration It is assumed that air injected by the aeration system is equally distributed over aerated parts of the model domain, and, that aeration does not affect water flow. Oxygen Transfer Rate (OTR) from air to water is formulated as (Tchobanoglous et al., 2003):

$$
\begin{aligned}
\mathrm{OTR} & =k_{L a, T}\left(S_{o}^{*}-S_{o}\right) \\
k_{L a, T} & =k_{L a, 20} \theta^{20-T}
\end{aligned}
$$

The coefficient $k_{L a, T}$ is assumed to dependent on the properties of the aeration system, AFR and temperature. $\theta$ is assumed to 1.024 (Tchobanoglous et al., 2003) and $S_{o}^{*}$ is computed according to (Weiss, 1970):

$$
\ln \left(S_{o}^{*}\right)=A_{1}+A_{2} \frac{100}{T}+A_{3} \ln \left(\frac{T}{100}\right)+A_{4} \frac{T}{100}+S_{\text {Sal }}\left(B_{1}+B_{2} \frac{T}{100}+B_{3}\left(\frac{T}{100}\right)^{2}\right)
$$

were, $A_{n}$ and $B_{n}$ are empirically derived parameters (Table S2). Atmospheric oxygen transfer is neglected due to its comparably low oxygen transfer coefficient of $0.132 \mathrm{~h}^{-1}$ (Samsó and García, 2013) compared to oxygen transfer coefficients of 1-10 $\mathrm{h}^{-1}$ estimated for mechanical aeration (Butterworth, 2014). More details and equations are given in Section S3.1-S3.2. 
Table 1: Parameters of the water flow and aeration processes.

\begin{tabular}{|c|c|c|}
\hline Parameter & Description & Unit \\
\hline \multicolumn{3}{|c|}{ Water Flow } \\
\hline $\mathrm{a}$ & Dispersion length & $\mathrm{m}$ \\
\hline g & Gravity acceleration & $\mathrm{m} \mathrm{s}^{-2}$ \\
\hline $\mathrm{k}_{r e l}$ & Relative permeability & \\
\hline $\mathrm{k}$ & Permeability & $\mathrm{m}^{2}$ \\
\hline $\mathrm{k}_{\alpha}$ & Permeability of the fast and slow flow field interface & $\mathrm{m}^{2}$ \\
\hline$p_{c}$ & Capillary pressure & $\mathrm{Pa}$ \\
\hline$p_{w}$ & Water pressure & $\mathrm{Pa}$ \\
\hline$Q_{w}$ & Source/sink term & $\mathrm{m}^{2} \mathrm{~s}^{-1}$ \\
\hline$S$ & Saturation & \\
\hline$t$ & Time & $\mathrm{s}$ \\
\hline$\alpha^{*}$ & Water transfer coefficient & $\mathrm{m}^{2}$ \\
\hline$\omega$ & Preferential factor & \\
\hline$\Gamma_{w}$ & Water exchange term & $\mathrm{s}^{-1}$ \\
\hline$\phi$ & Porosity & \\
\hline$\rho_{w}$ & Density of water & $\mathrm{kg} \mathrm{m}^{-3}$ \\
\hline$\mu_{w}$ & Dynamic viscosity of water & $\mathrm{Pas}$ \\
\hline \multicolumn{3}{|l|}{ Aeration } \\
\hline OTR & Oxygen transfer rate & $\operatorname{mg~L}{ }^{-1} h^{-1}$ \\
\hline$S_{\text {Sal }}$ & Salinity & $\mathrm{g} \mathrm{kg}^{-1}$ \\
\hline$S_{o}^{*}$ & Saturated dissolved oxygen concentration & $\mathrm{mg} \mathrm{L}^{-1}$ \\
\hline$S_{o}$ & Dissolved oxygen concentration & $\mathrm{mg} \mathrm{L}^{-1}$ \\
\hline$T$ & Temperature & ${ }^{\circ} \mathrm{C}$ \\
\hline$\theta$ & Temperature correction factor & \\
\hline
\end{tabular}

\subsection{Computational Model}

The mathematical model is implemented into a coupling of OpenGeoSys (v5.7.1), an open-source $\mathrm{C}++$ code for thermo-hydro-mechanical-chemical processes in porous-media (Kolditz et al., 2012), and IPHREEQC, a $\mathrm{C}++$ module of the geochemical code PHREEQC (Charlton and Parkhurst, 2011). The coupling uses a sequential non-iterative operator splitting scheme (He et al., 2015). For this study, all model components (solutes and particulates) and associated reactions are implemented as user defined species and functions in PHREEQC, respectively. Finite-element meshes were generated in GMSH (Geuzaine and Remacle, 2009), post-processing was conducted in R (v.3.3.2, R Core Team (2014)).

\subsection{Model Domain, Initial \& Boundary Conditions, Calibration \& Validation}

Model Domain, Initial and Boundary Conditions The model domain (Figure 1) was discretized into 94 finite-elements, each of $0.05 \mathrm{~m}$ in length; the time step size was set to $7200 \mathrm{~s}$. All model parameters including their source (if not calibrated, or measured) are listed in Section S3.3. According to the wetland water level of $0.9 \mathrm{~m}$, initial hydrostatic pressure was set to $8829 \mathrm{~Pa}$ over the entire domain. Water inflow was set as constant source term at rate of $6.666 \cdot 10^{-6} \mathrm{~m}^{3} \mathrm{~s}^{-1}$; at the outflow a Dirichlet-type condition of $8829 \mathrm{~Pa}$ was set. Initial concentrations of all solute and particulate pollutants were set to $0.1 \mathrm{mg} \mathrm{L}^{-1}$. Initial tracer concentrations were set to zero; initial bacteria concentrations were set to $1.0 \mathrm{mg} \mathrm{L}^{-1}$ to realize a rapid start-up. A time-dependent Dirichlet-type boundary condition based on measured influent water quality was defined at the domain inlet. Initial temperature for reactive transport calibration and cross-validation was set to the average water temperature measured at start of the aeration adaptation experiment. Time-dependent 
Dirichlet-type boundary conditions for water temperature were then defined at the inlet and outlet points (Section S3.4).

Influent Fractionation Organic matter related CWM1 components depend on $\mathrm{COD}_{\mathrm{t}}, \mathrm{COD}_{\mathrm{s}}$ and biodegradable $\mathrm{COD}_{\mathrm{t}}\left(\mathrm{BCOD}_{\mathrm{t}}\right) . \mathrm{COD}_{\mathrm{t}}, \mathrm{COD}_{\mathrm{s}}$ were not measured consistently, thus, missing values were imputed by regression on TOC and DOC measurements. $\mathrm{BCOD}_{\mathrm{t}}$ was estimated from $\mathrm{CBOD}_{5}$ measurements using occasional measurement of $\mathrm{CBOD}_{10}$ according to Roeleveld and Loosdrecht (2002). The influent was then fractionated analog to Roeleveld and Loosdrecht (2002) (Section S3.6). Influent values for sulphide sulfur $\left(S_{\mathrm{SO}_{4}}\right)$ and sulfate sulfur $\left(S_{\mathrm{H}_{2} \mathrm{~S}}\right)$ were set to constant levels of 56.6 and $8.6 \mathrm{mg} \mathrm{S} \mathrm{L}^{-1}$ (mean influent concentrations April 2012 to April 2013 reported by Saad (2017)), respectively.

Calibration and Validation of the Conservative Transport Model The conservative transport model was calibrated on tracer breakthrough curves (BTC) of the Test in four steps: 1) setting up the flow model; 2) manual calibrations of $\omega^{h k}, \mathrm{k}^{l k}, \mathrm{k}^{h k}, \phi^{l k}, \phi^{h k}, \mathrm{a}^{l k}$ and $\mathrm{a}^{h k}$ by visually comparing the simulated and measured uranine and bromide BTCs of the Test (an array of initial values was guessed based on expert knowledge, see Section S3.5); 3) optimizations of each manually calibrated array of parameters by minimization of the sum of squared-errors (SSQE) using the Levenberg-Marquardt algorithm provided by the parameter estimation tool PEST (Doherty, 2005); 4) choosing the final parameter set by comparing all optimization sets with respect to SSQE, $r$ and a visual inspection of the BTC fits. The parameter $\alpha^{*}$ was assumed to $100 \mathrm{~m}^{-2}$ (Kolditz et al., 2012). The model was then cross-validated by assessing the prediction accuracy on measured BTCs of the Control.

Calibration and Validation of the Reactive Transport Model Calibration of the RTM using the Test involved 1) a manual calibration of $k_{\text {att }}$ ( $k_{\text {det }}$ was set to zero) and $M_{\text {cap }}$ on porewater $\mathrm{COD}_{\mathrm{t}}$ concentrations, 2) the assumption of $M_{b i o, \max }$ and 3) the calibration of $k_{L a, 20}$ using measured effluent concentrations of $\mathrm{DO}, \mathrm{COD}_{\mathrm{t}}, \mathrm{COD}_{\mathrm{s}}, \mathrm{NH}_{4}-\mathrm{N}$ and $\mathrm{NO}_{3}-\mathrm{N}$ of the Test during the aeration adaptation experiment. The original parameter set of CWM1 (Langergraber et al., 2009) was left unchanged. Furthermore, calibrated $k_{L a, 20}$ was then regressed on the corresponding measured AFRs to derive a prediction equation for $k_{L a, 20}$. Directvalidation of the calibrated RTM was performed by comparing simulation outputs with measured porewater profiles of the Test. For cross-validation the Control was simulated using the calibrated RTM. As AFR of the Control were different, the corresponding $k_{L a, 20}$ were obtained from the derived $k_{L a, 20}$ prediction equation. To assess the cross-validation prediction accuracy, simulated effluent and porewater concentrations were compared with measurements of the Control.

\subsection{Model Sensitivity Analysis}

Local sensitivity analysis was performed on the calibrated model parameters to assess how a given change in a model parameter changes the model output (e.g. $S_{A}$ ). For each component-parameter pair a relative sensitivity function was computed according to Dochain and Vanrolleghem (2001):

$$
\Gamma_{n, m}(t)=\frac{\frac{\partial y_{n}(t)}{y_{n}(t)}}{\frac{\partial \xi_{m}}{\xi_{m}}}=\frac{\frac{\left(y_{n}\left(t, \xi_{m}+\delta \xi_{m}\right)-y_{n}\left(t, \xi_{m}\right)\right)}{y n\left(t, \xi_{m}\right)}}{\frac{\delta \xi_{m}-\xi_{m}}{\xi_{m}}}
$$

were $\Gamma_{n, m}(t)$ is the relative sensitivity of the $n$-th model component (e.g. $\left.S_{A}\right)$ to the $m$-th parameter $\xi_{m}$ (e.g. $k_{L a}$ ) over time $t, y(t)$ is the value of the $n$-th model component and $\delta$ is the change in a certain parameter. Then the relative influence of an individual parameter on a certain model component was computed as:

$$
\gamma_{n, m}=\frac{\sum_{t=0}^{t} \Gamma_{n, m}(t)}{\sum_{m=1}^{m} \sum_{t=0}^{t} \Gamma_{n, m}(t)}
$$

Two analysis were run: one on the tracer effluent concentrations of the calibrated conservative transport model, another on the model component concentrations (effluent and porewater) of the calibrated RTM; $\delta$ was chosen to 10 and $20 \%$. 


\subsection{Prediction Scenarios}

To investigate the link of AFR and temperature to $k_{L a, 20}$, and, $k_{L a, 20}$ to treatment performance, a hypothetical, continuously aerated HF wetland was simulated at eight different $k_{L a, 20}\left(0.5-6.0 \mathrm{~h}^{-1}\right)$ and different temperatures $\left(2.5-25.0^{\circ} \mathrm{C}\right)$ in two scenarios. The first scenario (I) consisted in a set of simulations with same initial and boundary conditions as during the cross-validation scenario except that $k_{L a, 20}$ was set to the same value over the entire model domain in each simulation (no difference between front and back grid). To remove the bias of variable influent quality on temperature during scenario I, influent concentrations were defined to be constant in scenario II (median influent concentrations of scenario I were used). Initial conditions were similar as in scenario I, except an initial temperature of $25^{\circ} \mathrm{C}$. Each simulation was started with a 20 days long phase at $25.0^{\circ} \mathrm{C}$, then temperature was decreased at a rate of $0.1 \mathrm{~K} \mathrm{~d}^{-1}$ to $2.5^{\circ} \mathrm{C}$ including a 10 days long resting phase at 20.0 and $15.0^{\circ} \mathrm{C}$, a 20 days long resting phase at $10.0^{\circ} \mathrm{C}$ and a 60 days long resting phase at 5.0 and $2.5^{\circ} \mathrm{C}$. The resting phases were set to achieve quasi steady-state conditions at each temperature level. Further information is provided in Section S3.4.3.

\section{Results and Discussion}

\subsection{Hydraulic Tracer Experiments}

Median in- and outflow of Test and Control during the tracer experiments were $577 \pm 2$ and $559 \pm 3 \mathrm{~L} \mathrm{~d}^{-1}$ as well as $578 \pm 2$ and $544 \pm 8 \mathrm{~L} \mathrm{~d}^{-1}$, respectively. Within Test and Control, bromide and uranine tracer breakthrough curves (BTC) exhibited similar peak and tracer mean retention times that indicate a similar transport behavior of both tracers, and, therefore strengthen the validity of the measurements (Figure 3 , Table 2). For the Test, tracer peak and mean retention time were 5-10\% lower and NTIS was 1.5-2.0 times lower compared to the Control. This expresses faster and more variable flow in the Test. However, strong tailing in the uranine BTCs and high bromide concentrations from day five to eight indicate preferential flow in both wetlands. Bromide recovery was relatively low compared to previously reported $82-89 \%$ from experiments in comparable aerated HF (Boog, 2013) and 69-81\% in conventional HF wetlands (Ayano, 2014). This was probably induced by bromide loss through problems with sample storage.

Table 2: Key parameters of the hydraulic tracer experiments.

\begin{tabular}{lclrc}
\hline System & $\tau(\mathrm{d})$ & NTIS (-) & $m_{\text {tracer,rec }}(-)$ & $e_{v}(-)$ \\
\hline Bromide & & & & \\
$\quad$ Test & 4.3 & 3.2 & 0.47 & 1.17 \\
$\quad$ Control & 4.8 & 5.2 & 0.64 & 1.28 \\
Uranine & & & & \\
$\quad$ Test & 4.5 & 2.2 & 0.83 & 1.20 \\
$\quad$ Control & 4.3 & 3.9 & 0.92 & 1.17 \\
\hline
\end{tabular}

nHRT of $3.5 \mathrm{~d}$ for Test and Control

\subsection{Aeration Adaptation Experiment}

Median hydraulic in- and outflow for Test and Control were $578 \pm 2$ and $552 \pm 18 \mathrm{~L} \mathrm{~d}^{-1}$, as well as, 578 \pm 0 and $567 \pm 19 \mathrm{~L} \mathrm{~d}^{-1}$, respectively. The influent shows typical water quality of high strength primarily treated domestic sewage (Tchobanoglous et al., 2003) (Table 3). During Phases 1-3 (Figure 4), both wetlands produced high quality effluents similar to effluent quality reported from previous experiments at the site (Boog et al., 2018) and the literature (Ilyas and Masih, 2017). Effluent concentrations and porewater patterns (Figure 5) indicate similar and stable operation of both wetlands through Phases 1-3 and from the mid of 


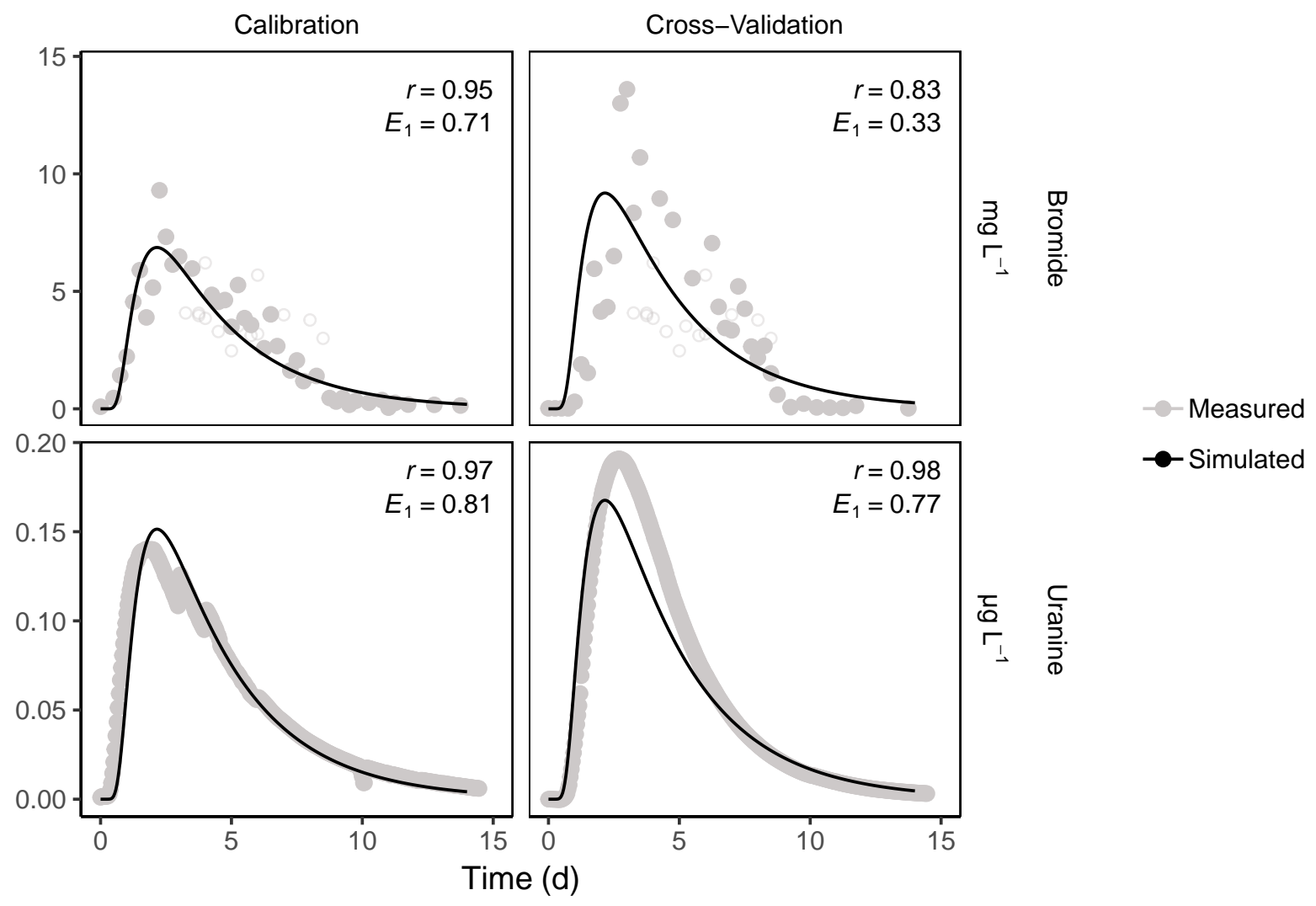

Figure 3: Measured and simulated tracer breakthrough curves for the calibration on system HM and crossvalidation scenario on system HMc of the transport model. Outliers (small circles) were caused by sample water loss and evaporation during storage and exlcuded from further analysis. 
Phase 5 on. In Phase 4, $\mathrm{NH}_{4}-\mathrm{N}$ effluent concentration of the Control increased due to inhibited nitrification by low water temperatures and elevated $\mathrm{NH}_{4}-\mathrm{N}$ influent concentration. In contrast, effluent $\mathrm{NO}_{\mathrm{x}}-\mathrm{N}$ decreased only at the time of the $\mathrm{NH}_{4}-\mathrm{N}$ peak, however, the corresponding $\mathrm{NO}_{\mathrm{x}}-\mathrm{N}$ porewater pattern was shifted about $0.7 \mathrm{~m}$ to the outlet (Figure 5). In the Test, AFR reduction in Phase 4 from $128-72 \mathrm{~L} \mathrm{~m}^{-2} \mathrm{~h}^{-1}$ decreased DO (Figure 5) and substantially inhibited nitrification (higher $\mathrm{NH}_{4}-\mathrm{N}$ and lower $\mathrm{NO}_{3}-\mathrm{N}$ effluent concentrations). In contrast, air flow reduction during Phases 1-3 did not substantially affect treatment performance of any parameters measured. After switching aeration in the Test back to approximately $400 \mathrm{~L} \mathrm{~m}^{-2} \mathrm{~h}^{-1}$ (Phase 5), $\mathrm{NH}_{4}-\mathrm{N}$ and $\mathrm{NO}_{\mathrm{x}}-\mathrm{N}$ treatment performance recovered within ten days to levels of prior phases.

Table 3: Influent concentrations during the aeration adaptation experiment.

\begin{tabular}{lllllllll}
\hline Parameter & $\mathrm{DO}$ & $\mathrm{CBOD}_{5}$ & $\mathrm{COD}_{\mathrm{t}}$ & $\mathrm{COD}_{\mathrm{s}}$ & $\mathrm{TOC}$ & $\mathrm{NH}_{4}-\mathrm{N}$ & $\mathrm{NO}_{x}-\mathrm{N}$ & Unit \\
\hline$n$ & 35 & 34 & 7 & 7 & 34 & 34 & 34 & \\
$c^{*}$ & $0.6 \pm 0.2$ & $289.4 \pm 94.2$ & $470.3 \pm 52.4$ & $246.4 \pm 41.6$ & $152.0 \pm 32.2$ & $60.4 \pm 11.5$ & $0.3 \pm 1.4$ & $\mathrm{mg} \mathrm{L}^{-1}$ \\
\hline
\end{tabular}

\subsection{Conservative Transport Model Calibration, Validation and Sensitivity Ana- lysis}

The dual-permeability based flow model assumes two overlapping flow fields with separate hydraulic characteristics, which allows the division into a faster and a slower moving flow field. As a result, short tracer peak times of the experimental BTCs could be fitted by the fast flow field and strong tailing by its slower counterpart, yielding an acceptable fit of the tracer BTCs of the Test ( $r$ of $0.95-0.97$, Nash-Stutcliffe efficiency $\left(E_{1}=\right)$ of $0.71-0.81$, Figure 3$)$.

The fact that Test exhibited preferential (Section 3.1) strengthened by a $50 \%$ share of the fast and slow flow field each and the deviation in their parameters (Table 4). For the fast flow field, hydraulic permeability $\mathrm{k}^{h k}$ is twice as high and dispersion length $\mathrm{a}^{h k}$ three times as high compared to $\mathrm{k}^{l k}$ and $\mathrm{a}^{l k}$. Calibrated $\mathrm{k}$ are in range with reported values of medium gravel and materials with similar particle size (Judge, 2013); calibrated a are similar to results from conventional HF wetlands (Pugliese et al., 2017; Samsó and García, 2013). Cross-validation with the Control exhibited the models ability to simulate the main hydraulic behavior of a comparable wetland with sufficient accuracy $\left(r=0.83-0.98, E_{1}=0.33-0.77\right.$, Figure 3$)$. However, the BTC peak for uranine as well as BTC peak and mid part for bromide were underestimated in the cross-validation, which was the result of the different flow behavior in Test and Control, induced by their different AFRs and spatial air distribution. Nevertheless, the contribution of each of the two factors cannot be clearly distinguished as porewater samples that could give insight into internal BTCs were not taken and potential effects of aeration on hydraulics were not included in the model. In fact, air bubble movement alters water saturation and therefore relative permeability and, thus hydraulic behavior. However, air bubble movement depends on AFR and a calibration of a function that relates both requires an extensive amount of specifically designed experiments. Therefore, aeration was assumed not to affect water flow in the current model.

Most critical parameters of the sensitivity analysis were $\phi^{h k}, \mathrm{k}^{l k}, a^{h k}$, and $\mathrm{k}^{h k}$ as these govern the center of the BTC and influence the BTC spread in conjunction with $\mathrm{a}^{h k}$ and $\mathrm{a}^{l k}$ (Figure 6). $\omega^{h k}$ had a lower influence; a change in $a^{l k}$ as well as $\alpha^{*}$ was almost of no importance. The sensitivity of $\phi^{l k}$ was not evaluated explicitly as it is tied to $\phi^{h k}$. The fast flow domain was more important for dispersion $\left(\Gamma_{\alpha^{h k}}>>\Gamma_{\alpha^{l k}}\right)$, whereas advection was more important for the slow flow domain $\left(\Gamma_{\mathrm{k}^{h k}}>\Gamma_{\mathrm{k}^{l k}}\right)$. Possibly a ${ }^{l k}$ and $\alpha^{*}$ were within a range of low influence and their sensitivities may increase at a change higher than $25 \%$ from their current values. These results do no present a clear picture of the hydraulics of the Test.

\subsection{Reactive Transport Model Calibration and Validation}

After a simulation start-up of 14-20 days, measured effluent concentrations and porewater profiles of the Test were well fitted by the calibration run (Figure 4). The high variability of simulated $\mathrm{NH} \sim 4-\mathrm{N}$ and $\mathrm{NO}_{\mathrm{x}}-\mathrm{N}$ in 

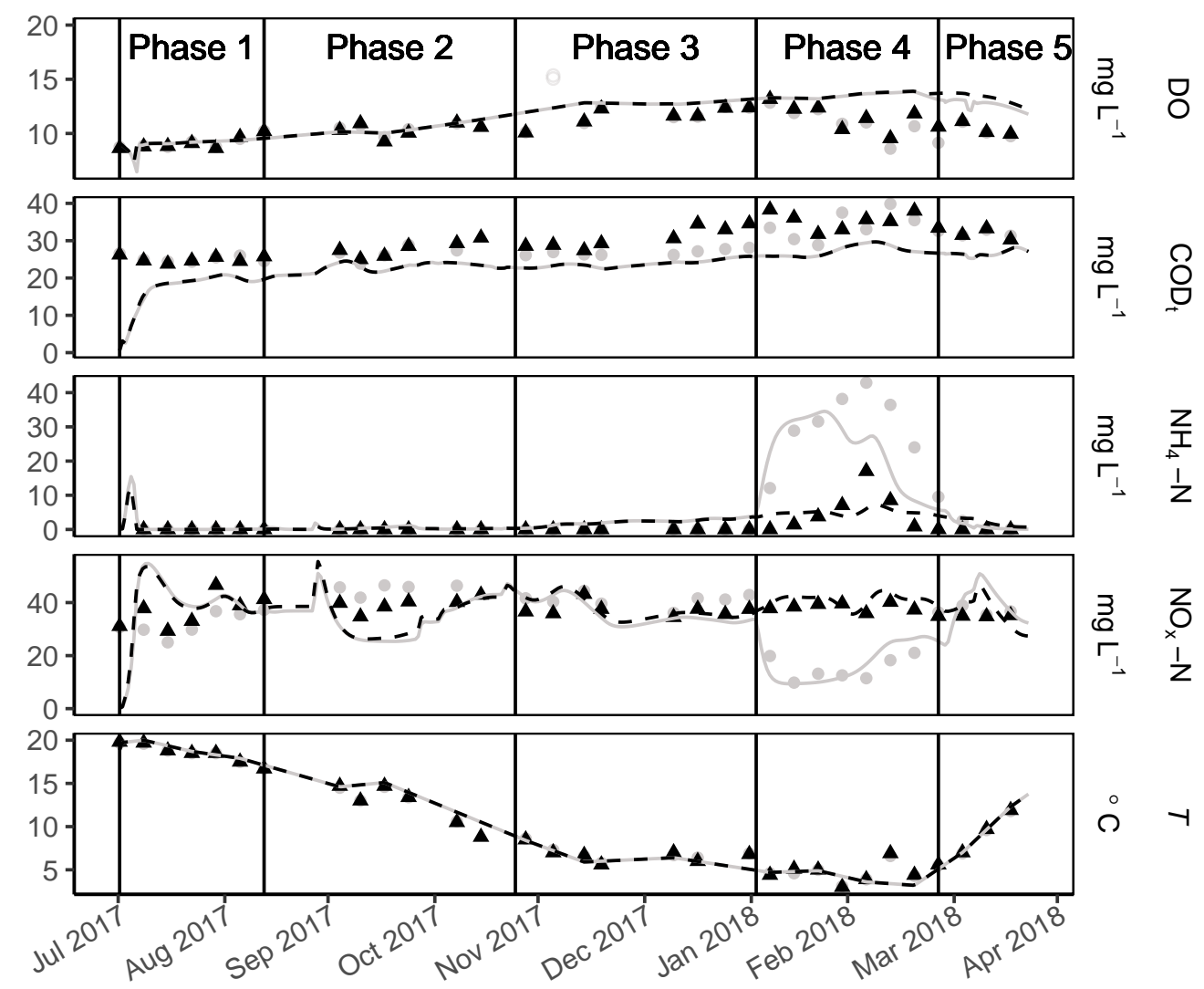

Figure 4: Measured (dots) and simulated (lines) effluent water quality during the aeration adaptation experiment. Outliers are indicated by small circles. Prediction accuracy of simulated effluent concentrations for calibration (cal) on Test and cross-validation (cv) on Control were $r_{\text {cal }}^{-}=0.69 \pm 0.27$ and $E_{1, \text { cal }}^{-}=$ $0.03 \pm 0.59$ as well as $r_{c v}^{-}=0.68 \pm 0.31$ and $E_{1, c v}^{-}=-0.43 \pm 0.72$, respectively. 


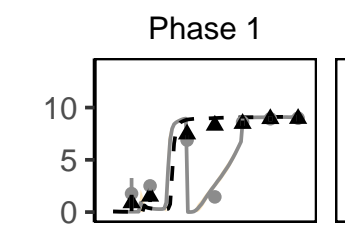

Phase 2
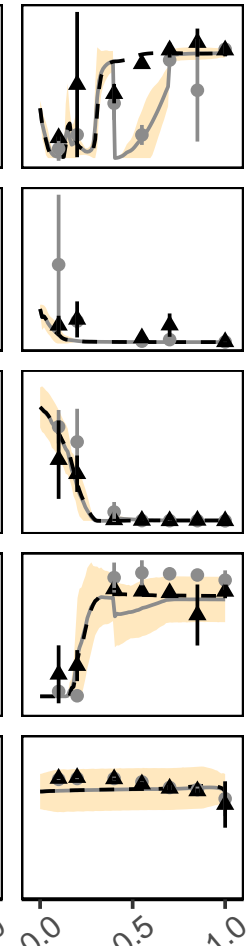

Phase 3
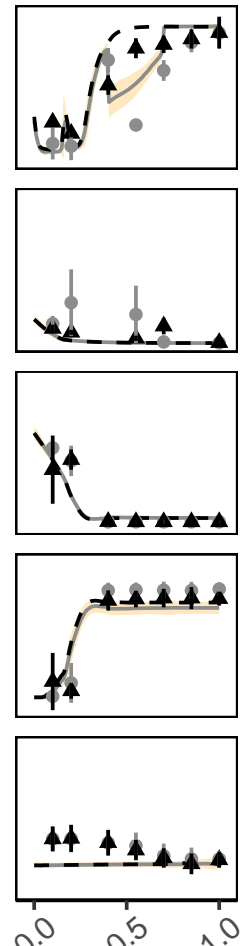

Phase 4
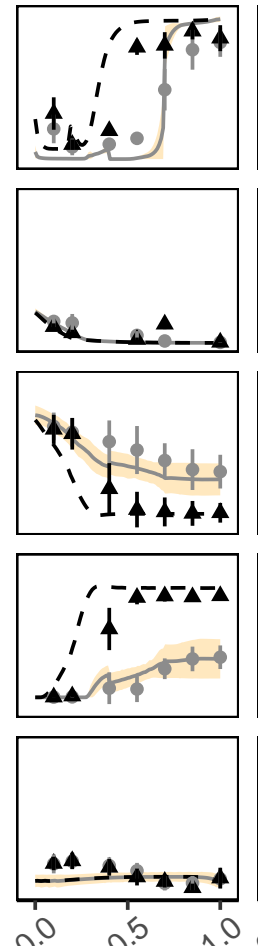

Phase 5
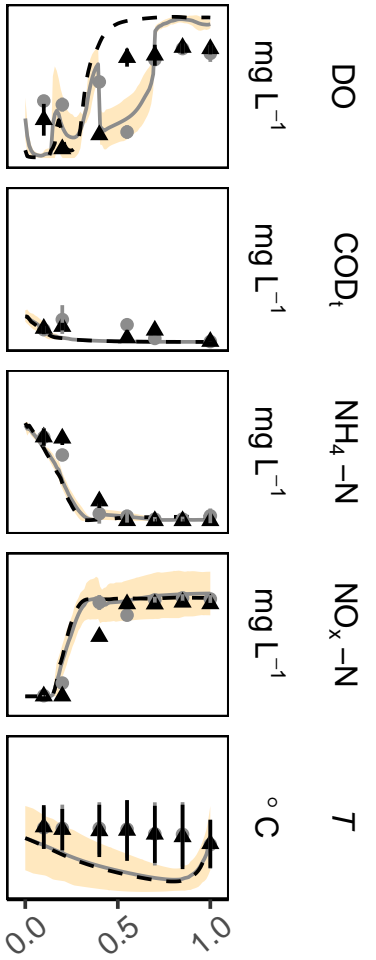

Fractional Length along Wetland

Figure 5: Measured (points) and simulated (lines) porewater profiles during the aeration adaptation experiment. Orange area defines variability of simulated profiles for calibration scenario. Accuracy for calibration (cal) on Test and cross-validation (cv) on Control were $r_{c a l}^{-}=0.81 \pm 0.09$ and $E_{1, c a l}^{-}=0.47 \pm 0.28$ as well as $r_{c v}^{-}=$ $0.79 \pm 0.10$ and $E_{1, c v}^{-}=0.40 \pm 0.27$, respectively. 
Table 4: Calibrated parameters of the conservative transport model $\left(r=0.97, E_{1}=0.76\right)$.

\begin{tabular}{lllllll}
\hline $\mathrm{a}^{h k}(\mathrm{~m})$ & $\mathrm{a}^{l k}(\mathrm{~m})$ & $\mathrm{k}^{h k}\left(\mathrm{~m}^{2}\right)$ & $\mathrm{k}^{l k}\left(\mathrm{~m}^{2}\right)$ & $\omega^{h k}(-)$ & $\phi^{h k}(-)^{*}$ & $\phi^{l k}(-)^{*}$ \\
\hline 2.50 & $7.5 \mathrm{e}-01$ & $4.0 \mathrm{e}-07$ & $8.0 \mathrm{e}-07$ & $5.0 \mathrm{e}-01$ & $3.0 \mathrm{e}-01$ & $4.6 \mathrm{e}-01$ \\
\hline
\end{tabular}

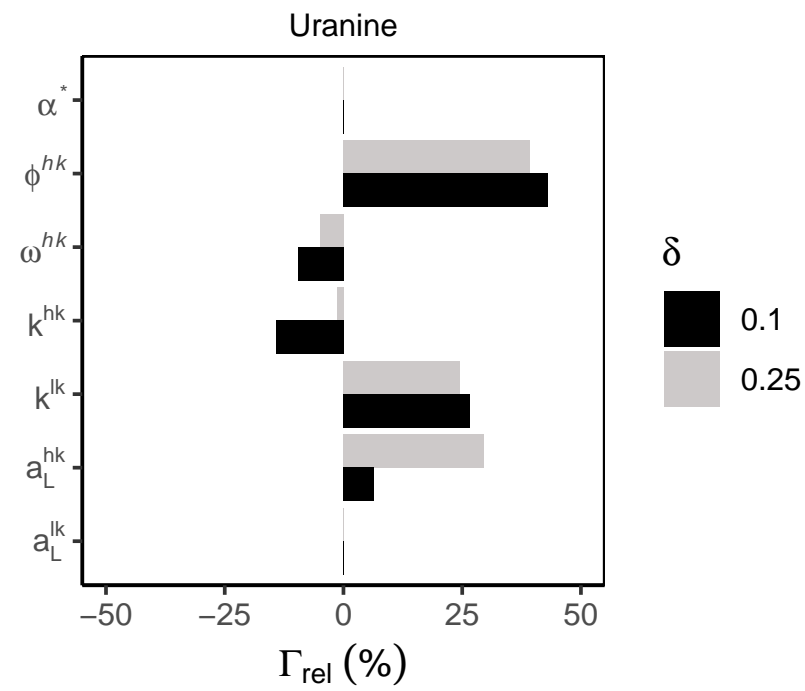

Figure 6: Percentage contribution $\left(\Gamma_{r e l}\right)$ of individual parameter sensitivities to the cummulative sensitivity for uranine. Relative sensitivity contribution of bromide was similar.

Phase 2 were caused by a sharp decrease in $\mathrm{NH}_{4}-\mathrm{N}$ influent concentration and a 10 days long stop of loading (due to a site failure). In Phase 4, simulated $\mathrm{NH}_{4}-\mathrm{N}$ concentrations of the Test recovered more rapid to prior values than measurements indicting that simulated nitrifying bacteria $\left(X_{A}\right)$ adapted more quickly to conditions of reduced AFR and low temperature than nitrifying bacteria in the experimental wetland. This is grounded in using temperature corrections for the biokinetic growth rate coefficient of nitrifying bacteria $\mu_{\max , X_{A}}$ that are recommend to be used within $10-20^{\circ} \mathrm{C}$ (Henze et al. (2000)). Consequently, extrapolating $\mu_{\max , X_{A}}$ to water temperatures below $10^{\circ} \mathrm{C}$ or above $20^{\circ} \mathrm{C}$ comes with the cost of increased uncertainty.

Measured porewater profiles of the Test are approximated with good accuracy (direct-validation), especially for DO and $\mathrm{NH}_{4}-\mathrm{N}$ in Phase 1-3 as well as DO, $\mathrm{NH}_{4}-\mathrm{N}$ and $\mathrm{NO}_{\mathrm{x}}-\mathrm{N}$ in Phase 2 and Phase 3 (Figure 5). Also, simulated $\mathrm{NH}_{4}-\mathrm{N}$ and $\mathrm{NO}_{3}-\mathrm{N}$ porewater patterns during Phase 4 deviated from the measurements due to the faster recovery of simulated nitrifiers.

The model can be interpreted as valid to simulate a comparable aerated wetland (cross-validation, Figure $4 \& 5$ ). However, accuracy lacks to represent $\mathrm{COD}_{\mathrm{t}}$ effluent concentrations and porewater profiles, which may be attributed to the diverging flow behavior in Test and Control. The lacking fit of $\mathrm{NH}_{4}-\mathrm{N}$ effluent concentrations in Phase 4 underlines that the temperature correction function of $\mu_{\max , X_{A}}$ is not optimal. Accuracy of the fit of measured porewater profiles of the Control during Phase 4 and Phase 5 could have been improved by setting a lower $k_{L a, 20}$ for the corresponding phases, however, $k_{L a, 20}$ was obtained from $k_{L a, 20}=0.511 \ln (\mathrm{AFR})$ (Figure 7). The lack of fit of porewater temperature profiles is grounded in the fact that air movement, which is induced by aeration and intensifies heat transfer in the experimental wetland is not simulated. Therefore, the model lacks sufficient boundary conditions for heat transport.

The equation $k_{L a, 20}=0.511 \ln (\mathrm{AFR})$ was obtained by regressing calibrated $k_{L a, 20}$ on measured AFRs of the Test ( $r^{2}=0.991, p<0.001$, Figure 7$)$. The sharp increase of $k_{L a, 20}$ at AFR $<150 \mathrm{~L} \mathrm{~m}^{-2} \mathrm{~h}^{-1}$ combined with 


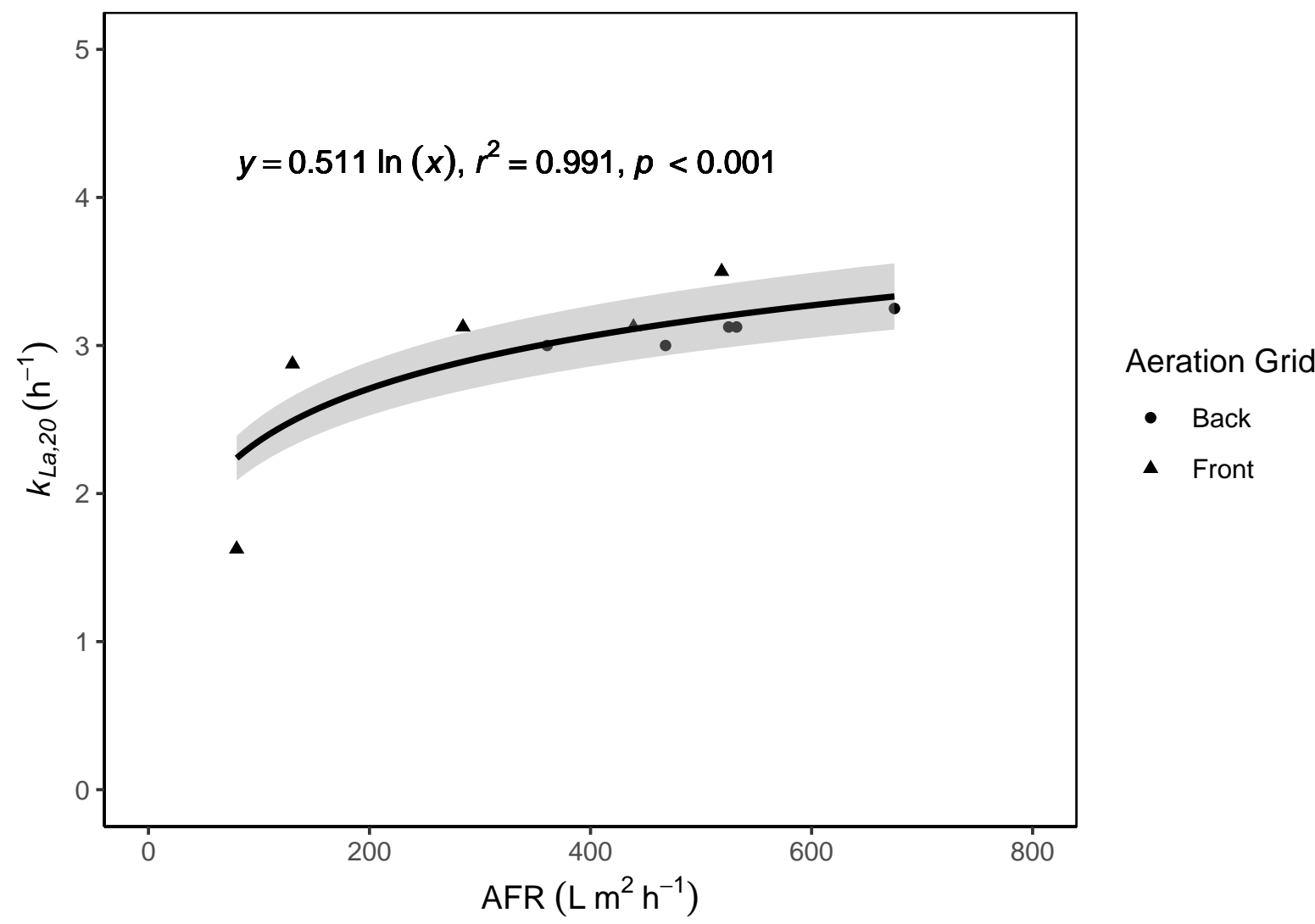

Figure 7: Oxygen transfer coefficients $k_{L a, 20}$ calibrated using the RTM vs. measured AFRs.

the fact that measured treatment performance reacted only to the AFR reduction in Phase 4 exhibits that treatment performance in the Test was highly sensitive to AFR $<150 \mathrm{~L} \mathrm{~m}^{-2} \mathrm{~L}^{-1}$. This is probably similar for aerated wetlands at similar operation conditions. The less accurate fit of the regression at low AFR may also be biased by the presence of surfactants that can reduce $k_{L a, 20}$ up to $50 \%$ (Wagner and Pöpel, 1996), however, this was not explicitly considered in this study. The model-based calibration of $k_{L a, 20}$ did not yield optimal values for the aeration back grid as the back grid affected treatment performance less because microbial metabolization hot-spots were located at the wetland front. Additionally, the obtained relationship of $k_{L a, 20}$ to AFR depends on the aeration system and bed media of the experimental wetland and, thus, may differ for a different aeration system or bed media.

In contrast to the obtained logarithmic relationship, Butterworth (2014) and Germain et al. (2007) reported an almost linear relationship of $k_{L a, 20}$ with AFR. However, both authors used different experimental set-ups, examined a different range of AFR and report highly variable results. At comparable AFRs (e.g. $290 \mathrm{~L} \mathrm{~h}^{-1}$ $\mathrm{m}^{-2}$ ) calibrated transfer coefficients of this study are half compared to values by Butterworth (2014), which was probably caused by methodological differences: wastewater vs. clean water and model-based versus measurement-based estimation of $k_{L a, 20}$.

\subsection{Reactive Transport Model Sensitivity Analysis}

Most sensitive parameters were $\phi^{h k}, \mathrm{k}^{h k}, \mathrm{a}^{h k}$ and $k_{L a, 20, \text { front }}$ (Figure 8-9). Bacteria exhibited similar sensitivity patterns and were sensitive to most parameters except $\alpha^{*}$ and $a^{l k}$. These two parameters were already identified to be unimportant for the conservative transport model (Section 3.3). On the other 


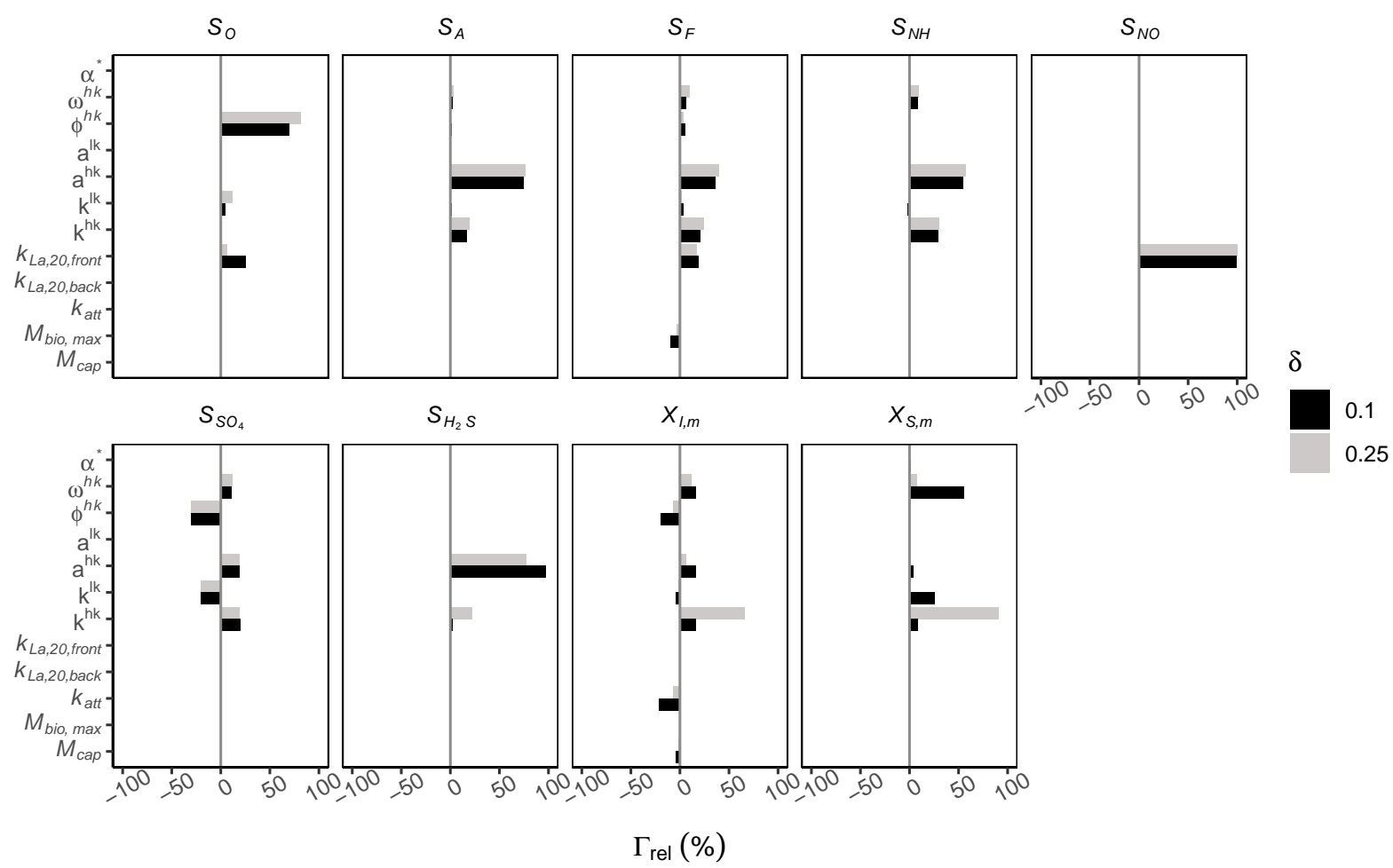

Figure 8: Percentage contribution $\left(\Gamma_{r e l}\right)$ of individual parameter sensitivities to the cummulative sensitivity for soluble and particulate substrate components.

hand, $\mathrm{a}^{h k}$ turned out to be important for all bacteria as it effects substrate spreading, and, therefore, living conditions for bacterial growth. In contrast, Langergraber (2001) noticed less sensitivity of bacteria to the dispersion length (a), however, in simulations of unsaturated vertical flow wetlands using different biokinetic formulations. Moreover, the high number of parameters bacteria are sensitive to was caused by the dependency of bacterial growth functions on multiple substrate components. Therefore, bacteria also incorporate the sensitivities of associated substrate components.

In contrast, non-bacteria components highly varied in their sensitivities to individual parameters. For example, ammonia nitrogen $S_{N H}$ did not show any substantial sensitivity to $k_{L a, 20, \text { front }}$, indeed, oxidized nitrogen $S_{N O}$ did show it, which was not expected as both components strongly depend on available DO $\left(S_{O}\right)$. Furthermore, it was assumed that $S_{N O}$ would be sensitive to the main transport parameters as was readily biodegradable $\mathrm{COD}_{\mathrm{t}} S_{F}$ or $S_{N H}$, because the production of $S_{N} O$ by heterotrophic bacteria $X_{H}$ depends on available $S_{F}$ (or $S_{A}$ ). Here, the parameter perturbation probably was too low. Additionally, a few model components exhibited different sensitivities for a given parameter whether it was changed by 10 or $25 \%$, which means that sensitivity functions look different at different parameter values. For example, Samsó et al. (2015) reported COD and $S_{N H}$ effluent concentrations of conventional HF wetland to be sensitive to $M_{c a p}$ and $M_{b i o, \max }$. This was not observed in this study as the current model does not include the effect of $M_{c} a p$ on bacterial growth functions (only on the attachment of $X_{I, m}$ ) and this study evaluated the sensitivity of effluent and porewater concentrations. Additionally, Samsó et al. (2015) used a lower value of $M_{b i o, \max }$, which corresponds to a different region in the respective sensitivity function. 


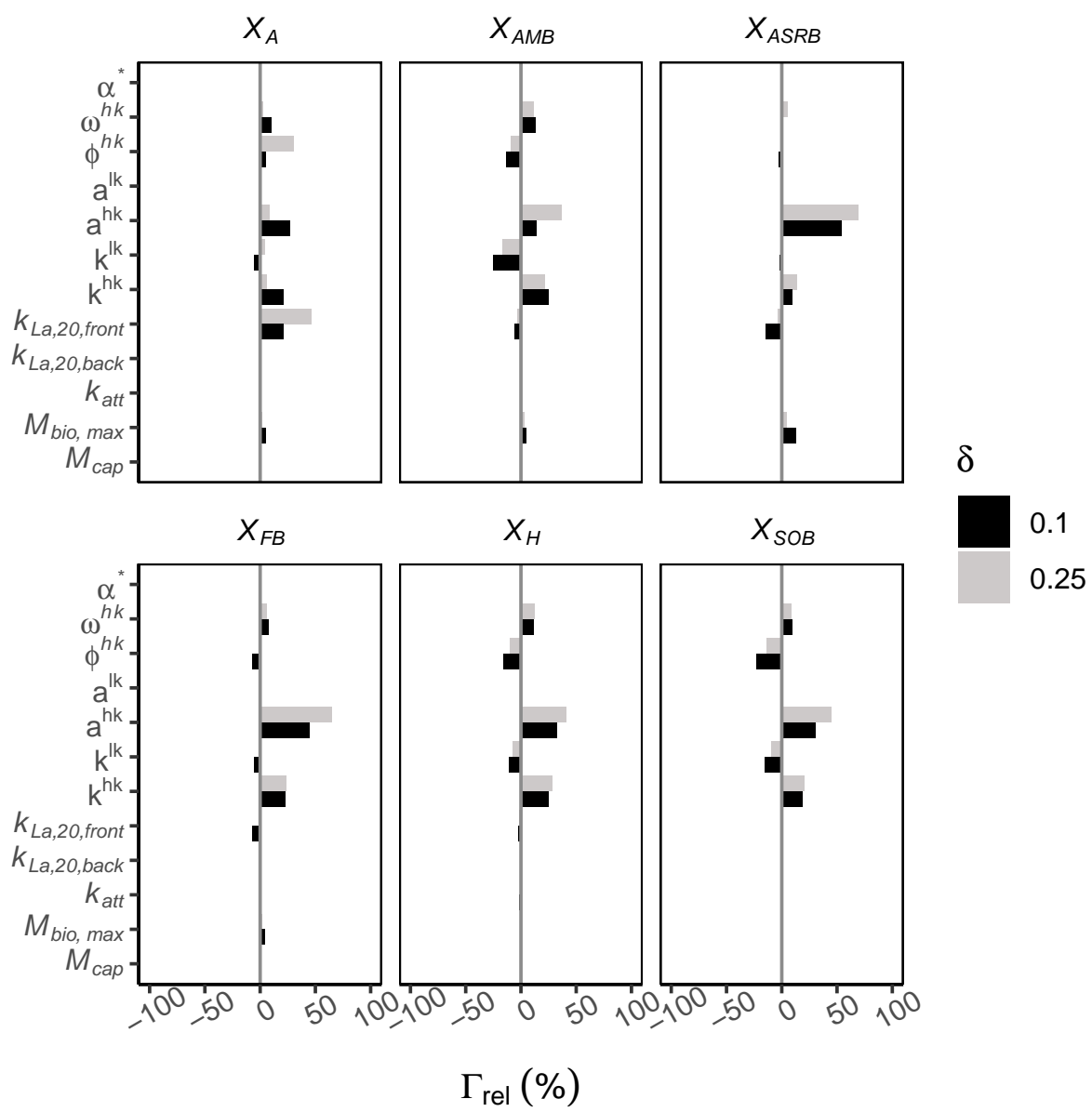

Figure 9: Percentage contribution $\left(\Gamma_{r e l}\right)$ of individual parameter sensitivities to the cummulative sensitivity for individual bacteria groups. 


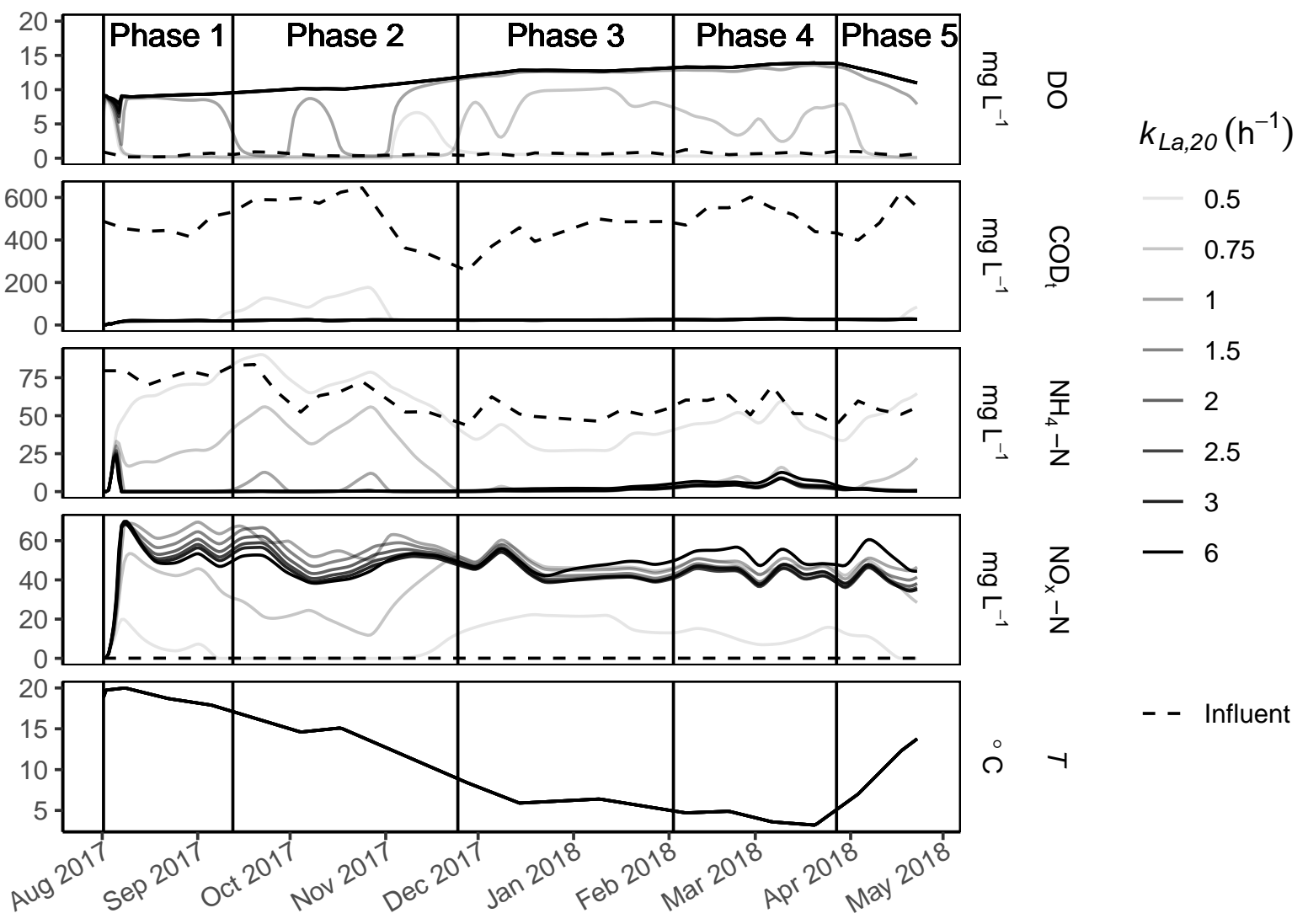

Figure 10: Simulated effluent concentrations of prediction scenario I. 


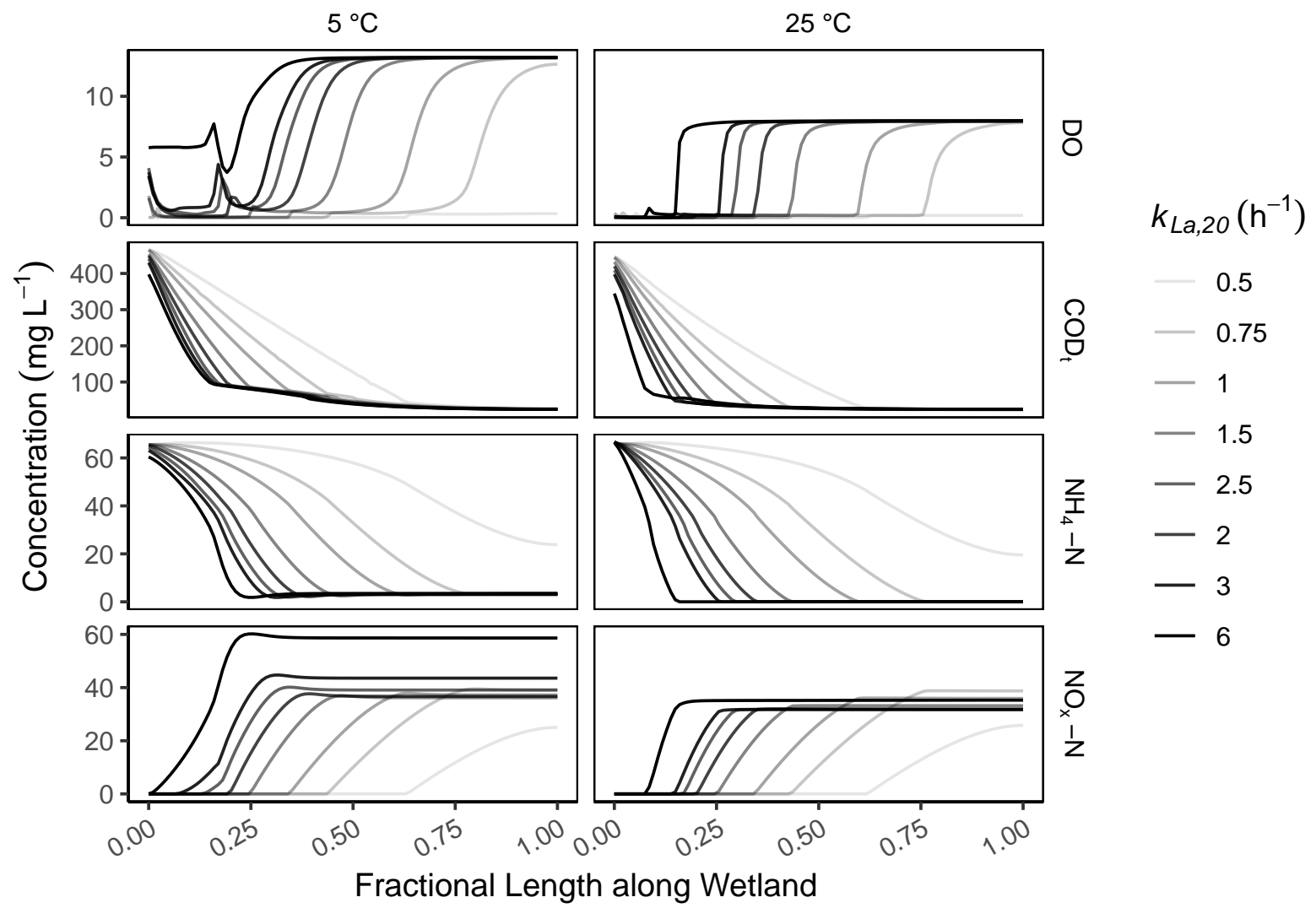

Figure 11: Simulated porewater concentration gradients at the end of resting phases at 5 and $25^{\circ} \mathrm{C}$ in prediction scenario II.

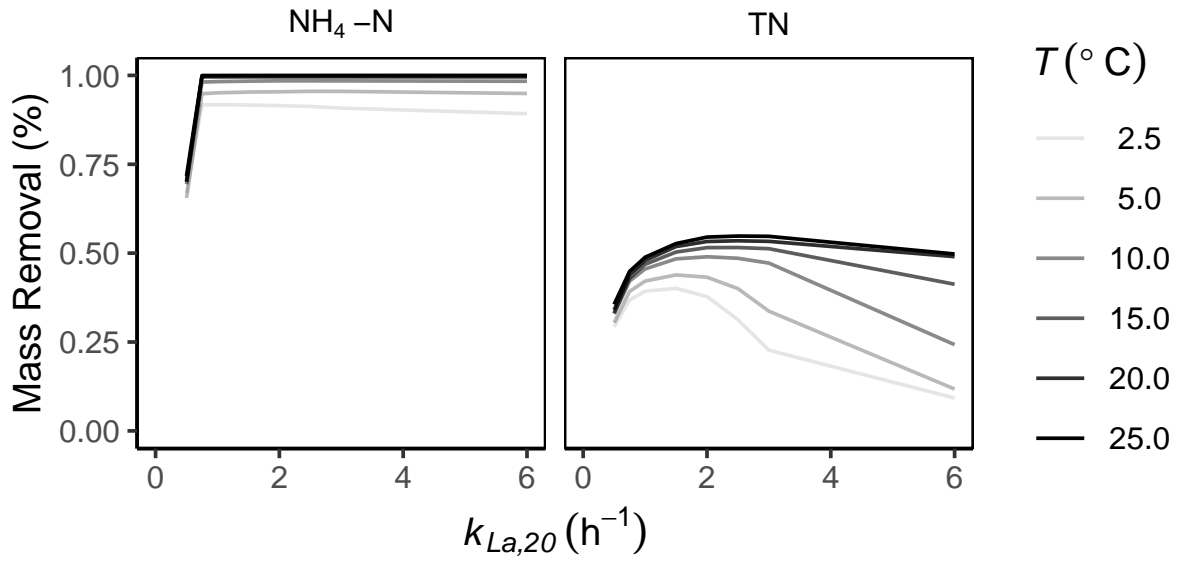

Figure 12: Simulated removal of $\mathrm{NH}_{4}-\mathrm{N}$ and $\mathrm{TN}$ at the end of resting phases in prediction scenario II. 


\subsection{Influence of Air Flow Rate, Oxygen Transfer Coefficient and Temperature on Treatment Performance}

All simulations of scenario I, except at $k_{L a, 20}<1.5 \mathrm{~h}^{-1}$, took 14-20 days to reach a quasi steady-state performance. Simulated nitrogen removal performance at $k_{L a, 20}$ of $0.5-1.5 \mathrm{~h}^{-1}$ deviated from the remaining simulations (seen in high $\mathrm{NH}_{4}-\mathrm{N}$ and low $\mathrm{NO}_{\mathrm{x}}-\mathrm{N}$ concentrations), which was induced by DO limitation (Figure 10). The limitation disappeared during Phase 3 and Phase 4 as influent strength decreased. The peaks of $\mathrm{COD}_{\mathrm{t}}$ concentrations at $k_{L a, 20}$ of $0.5 \mathrm{~h}^{-1}$ were caused by peaks in inflow concentrations and resulting DO limitations. Effluent $\mathrm{COD}_{\mathrm{t}}$ concentrations of the remaining simulations were in the range of $40-50 \mathrm{mg} \mathrm{L}^{-1}$. $\mathrm{NH}_{4}-\mathrm{N}$ and $\mathrm{NO}_{\mathrm{x}}-\mathrm{N}$ concentrations increased at temperatures below $7^{\circ} \mathrm{C}$ in all simulations at $k_{L a, 20}>0.5$ $\mathrm{h}^{-1}$ as a results of decreasing bacterial activity, however the intensity of this decrease differed across $k_{L a, 20}$.

In scenario II, influent strength was kept constant at the median of scenario I and temperature was decreased stepwise from $25.0-2.5^{\circ} \mathrm{C}$. With increasing $k_{L a, 20}$, simulated concentration gradients of $\mathrm{DO}, \mathrm{COD}_{\mathrm{t}}, \mathrm{NH}_{4}-\mathrm{N}$ as well as $\mathrm{NO}_{\mathrm{x}}-\mathrm{N}$ increased and shifted to shorter length in a declining manner: an increase from $k_{L a, 20}$ of $0.5-1.5 \mathrm{~h}^{-1}$ had a higher impact than an increase from 1.5-2.5 $\mathrm{h}^{-1}$ (Figure 11). In general, temperature affected oxygen transfer only marginal as the decrease in $k_{L a, 20}$ at lower temperature was counter-balanced by an increase in $S_{o}^{*}$ due to increased oxygen solubility. Temperature substantially affected only DO and $\mathrm{NO}_{\mathrm{x}}-\mathrm{N}$ concentration gradients, especially at $k_{L a, 20}>2.5 \mathrm{~h}^{-1}$. In combination with decreased bacterial activity, and, therefore decreased DO consumption, especially by nitrifying bacteria, this resulted in DO peaks at 0-5\% and $20-25 \%$ of length at $k_{L a, 20}>2.5 \mathrm{~h}^{-1}$. Such high DO levels further inhibited the activity of denitrifying bacteria $X_{H}$ and decreased $\mathrm{NO}_{\mathrm{x}}-\mathrm{N}$ removal rate at high $k_{L a, 20}$ (Figures $11 \& 12$ ). Thus, aeration at $k_{L a, 20}>$ $3.0 \mathrm{~h}^{-1}$ may results in lower $\mathrm{NO}_{\mathrm{x}}-\mathrm{N}$ removal at low temperature and comparable influent strength.

Combining results from scenarios I and II, a $k_{L a, 20}$ of $1.5 \mathrm{~h}^{-1}$, which corresponds to an AFR of approximately 50-100 L h- ${ }^{1} \mathrm{~m}^{-2}$ (Figure 7), was sufficient to reach 93\% removal of biodegradable organic carbon and $92 \%$ removal for $\mathrm{NH}_{4}-\mathrm{N}$ as well as DO saturation. This was most energy efficient aeration. However, most optimal aeration to remove nitrogen was at $k_{L a, 20}$ of $1.5-2.5 \mathrm{~h}^{-1}$, which corresponds to an AFR of $100-150 \mathrm{~L} \mathrm{~m}^{-2}$ $\mathrm{h}^{-1}$. Here, DO availability was higher, which counteracted denitrification, but, carbon supply to denitrifiers was enhanced due to the shorter travel path to denitrification hot spots. Despite this, AFR fluctuations at 100-150 L m${ }^{-2} \mathrm{~h}^{-1}$ will perturbe $k_{L a, 20}$ more intense than at $200-300 \mathrm{~L} \mathrm{~m}^{-2} \mathrm{~h}^{-1}$ (Figure 7). In conjunction with fluctuating influent strength this may complicate the control of redox gradients and would decrease overall treatment robustness. Therefore, aeration at AFR $>200 \mathrm{~L} \mathrm{~m}^{-2} \mathrm{~h}^{-1}$ seem to be more reliable to ensure a minimum OTR, in contrast, TN removal would then decrease. This highlights that treatment efficiency and robustness of aerated wetlands require different AFR and might not be maximized at once. Therefore, a compromise for continuously aerated wetlands with a similar aeration system treating domestic sewage of similar strength would be an AFR of $150-200 \mathrm{~L} \mathrm{~m}^{-2} \mathrm{~h}^{-1}$. This translates into a three to four times lower AFR than required by current design guidelines (DWA, 2018).

\section{Conclusion}

- A reactive transport model for aerated wetlands was developed, calibrated and successfully validated by pilot-scale experiments.

- The model reliably simulated hydraulic behavior as well as treatment performance of $\mathrm{COD}_{\mathrm{t}}, \mathrm{NH}_{4}-\mathrm{N}$, and $\mathrm{NO}_{\mathrm{x}}-\mathrm{N}$.

- Model calibration exhibited a non-linear and declining relationship of AFR with oxygen transfer coefficient $k_{L a, 20}$ and of $k_{L a, 20}$ with treatment performance for DO, $\mathrm{COD}_{\mathrm{t}}, \mathrm{NH}_{4}-\mathrm{N}$, and $\mathrm{NO}_{\mathrm{x}}-\mathrm{N}$.

- The model can support the design of new aerated wetland research experiments and engineering applications. Moreover, it can assist in spatially adjusting aeration to create a redox zonation, which can unfold the complete removal potential of aerated wetlands.

- For a continuously aerated horizontal flow wetland, an AFR of 150-200 $\mathrm{L} \mathrm{m}^{-2} \mathrm{~h}^{-1}$ would be a compromise between efficiency and robustness with respect to secondary treatment of organic carbon and nitrogen 
of domestic influent of similar strength. This corresponds to a three to four times lower AFR than required by current design guidelines and, thus, highlights an optimization potential from an economical and ecological standpoint.

\section{Acknowledgements}

This work was funded by the German Federal Ministry of Education and Research (BMBF) within the context of the SMART-MOVE project (Ref. 02WM1355). Johannes Boog acknowledges the Helmholtz Centre for Environmental Research (UFZ) GmbH . The authors gratefully acknowledge Katy Bernhard and Thomas Aubron for support and assistance in sample collection; Grit Weichert, Karsten Marien and Jürgen Steffen for analytical support; Eunseon Jang for the introduction to PHREEQC.

\section{Supplementary Information}

Supplementary information is presented in si.pdf. All model input files are supplied in model_input.zip. The OpenGeoSys source code (incl. the coupling to IPHREEQC) is available at https://github.com/ufz/ogs5.

\section{References}

Ayano, K.K., 2014. Effect of depth and plants on pollutant removal in horizontal subsurface flow constructed wetlands and their application in Ethiopia (PhD thesis). Technische Universität Berlin, Fakultät VI - Planen Bauen Umwelt. https://doi.org/10.14279/depositonce-3931

Boog, J., 2017. Application: Treatment wetlands, in: OpenGeoSys Tutorial. Springer International Publishing, pp. 63-90. https://doi.org/10.1007/978-3-319-67153-6_7

Boog, J., 2013. Effect of the aeration scheme on the treatment performance of intensified treatment wetland systems (Diploma Thesis). TU Bergakademie Freiberg; Institut für Thermische-, Umwelt- und Naturstoffverfahrenstechnik, Freiberg, Germany.

Boog, J., Nivala, J., Aubron, T., Mothes, S., Afferden, M. van, Müller, R.A., 2018. Resilience of carbon and nitrogen removal due to aeration interruption in aerated treatment wetlands. Science of The Total Environment 621, 960-969. https://doi.org/https://doi.org/10.1016/j.scitotenv.2017.10.131

Butterworth, E., 2014. The use of artificial aeration in horizontal sub-surface flow constructed wetlands for tertiary nitrification (PhD thesis). Cranfield University, School of Applied Sciences.

Charlton, S.R., Parkhurst, D.L., 2011. Modules based on the geochemical model PHREEQC for use in scripting and programming languages. Computers \& Geosciences 37, 1653-1663. https://doi.org/http: //dx.doi.org/10.1016/j.cageo.2011.02.005

Dochain, D., Vanrolleghem, P.A., 2001. Dynamical modelling \& estimation in wastewater treatment processes. IWA Publishing. https://doi.org/10.2166/9781780403045

Doherty, J., 2005. PEST: Software for model-independent parameter estimation, Watermark Numerical Computing, Brisbane, Australia.

DWA, 2018. Principles for dimensioning, construction and operation of wastewater treatment plants with planted and unplanted filters for treatment of domestic and municipal wastewater. DWA-A 262. German Association for Water, Wastewater and Waste.

Gerke, H., van Genuchten, M., 1993. A dual-porosity model for simulating the preferential movement of water and solutes in structured porous media. Water Resources Research 29, 305-319. https://doi.org/10. $1029 / 92 \mathrm{wr} 02339$ 
Germain, E., Nelles, F., Drews, A., Pearce, P., Kraume, M., Reid, E., Judd, S.J., Stephenson, T., 2007. Biomass effects on oxygen transfer in membrane bioreactors. Water Research 41, 1038-1044.

Geuzaine, C., Remacle, J.-F., 2009. Gmsh: A 3-d finite element mesh generator with built-in pre-and post-processing facilities. International Journal for Numerical Methods in Engineering 79, 1309-1331. https://doi.org/https://doi.org/10.1002/nme.2579

He, W., Beyer, C., Fleckenstein, J.H., Jang, E., Kolditz, O., Naumov, D., Kalbacher, T., 2015. A parallelization scheme to simulate reactive transport in the subsurface environment with ogs\#IPhreeqc 5.5.7-3.1.2. Geoscientific Model Development 8, 3333-3348. https://doi.org/10.5194/gmd-8-3333-2015

Henze, M., Gujer, W., Mino, T., Van Loosdrecht, M., 2000. Activated sludge models asm1, asm2, asm2d and asm3. IWA Publishing.

Ilyas, H., Masih, I., 2017. The performance of the intensified constructed wetlands for organic matter and nitrogen removal: A review. Journal of Environmental Management 198, 372-383. https://doi.org/10.1016/j. jenvman.2017.04.098

Judge, A., 2013. Measurement of the hydraulic conductivity of gravels using a laboratory permeameter and silty sands using field testing with observation wells ( $\mathrm{PhD}$ thesis). University of Massachusetts Amherst.

Kadlec, R.H., Wallace, S.D., 2009. Treatment wetlands, 2nd ed. CRC Press, Boca Raton, FL.

Kolditz, O., Bauer, S., Bilke, L., Böttcher, N., Delfs, J.O., Fischer, T., Görke, U.J., Kalbacher, T., Kosakowski, G., McDermott, C.I., Park, C.H., Radu, F., Rink, K., Shao, H., Shao, H.B., Sun, F., Sun, Y.Y., Singh, A.K., Taron, J., Walther, M., Wang, W., Watanabe, N., Wu, Y., Xie, M., Xu, W., Zehner, B., 2012. OpenGeoSys: An open-source initiative for numerical simulation of thermo-hydro-mechanical/chemical (THM/C) processes in porous media. Environmental Earth Sciences 67, 589-599. https://doi.org/10.1007/s12665-012-1546-x

Kolditz, O., Görke, U.J., Shao, H., Wang, W. (Eds.), 2012. Thermo-hydro-mechanical-chemical processes in fractured-porous media: Benchmarks and examples, Lecture Notes in Computational Science and Engineering. ed. Springer-Verlag Berlin Heidelberg. https://doi.org/10.1007/978-3-642-27177-9

Langergraber, G., 2017. Applying process-based models for subsurface flow treatment wetlands: Recent developments and challenges. Water 9. https://doi.org/10.3390/w9010005

Langergraber, G., 2001. Development of a simulation tool for subsurface flow constructed wetlands (PhD thesis). Wiener Mitteilungen, 169th ser. University of Natural Resources and Life Sciences, Vienna.

Langergraber, G., Rousseau, D.P.L., García, J., Mena, J., 2009. CWM1: A general model to describe biokinetic processes in subsurface flow constructed wetlands. Water Science and Technology 59, 1687-1697. https://doi.org/10.2166/wst.2009.131

Langergraber, G., Simunek, J., 2012. Reactive transport modeling of subsurface flow constructed wetlands using the hydrus wetland module. Vadose Zone Journal 11. https://doi.org/10.2136/vzj2011.0104

Li, F., Lu, L., Zheng, X., Zhang, X., 2014. Three-stage horizontal subsurface flow constructed wetlands for organics and nitrogen removal: Effect of aeration. Ecological Engineering 68, 90-96. https://doi.org/http: //dx.doi.org/10.1016/j.ecoleng.2014.03.025

Mayer, K.U., Frind, E.O., Blowes, D.W., 2002. Multicomponent reactive transport modeling in variably saturated porous media using a generalized formulation for kinetically controlled reactions. Water Resources Research 38, 13-1-13-21. https://doi.org/10.1029/2001WR000862

Nivala, J., Headley, T., Wallace, S., Bernhard, K., Brix, H., van Afferden, M., Müller, R.A., 2013. Comparative analysis of constructed wetlands: The design and construction of the ecotechnology research facility in Langenreichenbach, Germany. Ecological Engineering 61, 527-543. https://doi.org/10.1016/j.ecoleng.2013.01. 035

Pálfy, T.G., Gribovszki, Z., Langergraber, G., 2015. Design-support and performance estimation using hydrus/cw2d: A horizontal flow constructed wetland for polishing sbr effluent. Water Science and Technology 71, 965-970. https://doi.org/10.2166/wst.2015.052 
Pruess, K., 2004. The tough codes-a family of simulation tools for multiphase flow and transport processes in permeable media. Vadose Zone Journal 3, 738-746. https://doi.org/10.2113/3.3.738

Pugliese, L., Bruun, J., Kjaergaard, C., Hoffmann, C.C., Langergraber, G., 2017. Non-equilibrium model for solute transport in differently designed biofilters targeting agricultural drainage water. Water Science and Technology 76, 1324-1331. https://doi.org/10.2166/wst.2017.298

R Core Team, 2014. R: A language and environment for statistical computing. R Foundation for Statistical Computing, Vienna, Austria.

Roeleveld, P., Loosdrecht, M. van, 2002. Experience with guidelines for wastewater characterisation in the Netherlands. Water Science and Technology 45, 77-87.

Saad, R.A., 2017. Influence of system type, loading regimes and helophyte species on inorganic sulfur transformations in constructed wetlands (PhD thesis). Otto-von-Guericke-Universität Magdeburg, Faculty of Process and Systems Engineering.

Samsó, R., Blázquez, J., Agulló, N., Grau, J., Torres, R., García, J., 2015. Effect of bacteria density and accumulated inert solids on the effluent pollutant concentrations predicted by the constructed wetlands model BIO_PORE. Ecological Engineering 80, 172-180. https://doi.org/https://doi.org/10.1016/j.ecoleng.2014.09. 069

Samsó, R., García, J., 2013. BIO_PORE, a mathematical model to simulate biofilm growth and water quality improvement in porous media: Application and calibration for constructed wetlands. Ecological Engineering 54, 116-127. https://doi.org/10.1016/j.ecoleng.2013.01.021

Sanchez-Ramos, D., Agulló, N., Samsó, R., García, J., 2017. Effect of key design parameters on bacteria community and effluent pollutant concentrations in constructed wetlands using mathematical models. Science of The Total Environment 584-585, 374-380. https://doi.org/https://doi.org/10.1016/j.scitotenv.2017.01.014

Tchobanoglous, G., Burton, F.L., Stensel, H.D., 2003. Wastewater engineering: Treatment and reuse, 4th ed. McGraw-Hill, Boston.

Uggetti, E., Hughes-Riley, T., Morris, R.H., Newton, M.I., Trabi, C.L., Hawes, P., Puigagut, J., García, J., 2016. Intermittent aeration to improve wastewater treatment efficiency in pilot-scale constructed wetland. Science of The Total Environment 559, 212-217. https://doi.org/http://dx.doi.org/10.1016/j.scitotenv.2016.03.195

Wagner, M., Pöpel, J., H., 1996. Surface active agents and their influence on oxygen transfer. Water Science and Technology 34, 249. https://doi.org/10.2166/wst.1996.0438

Weiss, R., 1970. The solubility of nitrogen, oxygen and argon in water and seawater. Deep Sea Research and Oceanographic Abstracts 17, 721-735. https://doi.org/https://doi.org/10.1016/0011-7471(70)90037-9

Wu, H., Fan, J., Zhang, J., Ngo, H.H., Guo, W., Hu, Z., Lv, J., 2016. Optimization of organics and nitrogen removal in intermittently aerated vertical flow constructed wetlands: Effects of aeration time and aeration rate. International Biodeterioration \& Biodegradation 113, 139-145. https://doi.org/https: //doi.org/10.1016/j.ibiod.2016.04.031

Zhou, X., Gao, L., Zhang, H., Wu, H., 2018. Determination of the optimal aeration for nitrogen removal in biochar-amended aerated vertical flow constructed wetlands. Bioresource Technology 261, 461-464. https://doi.org/https://doi.org/10.1016/j.biortech.2018.04.028 